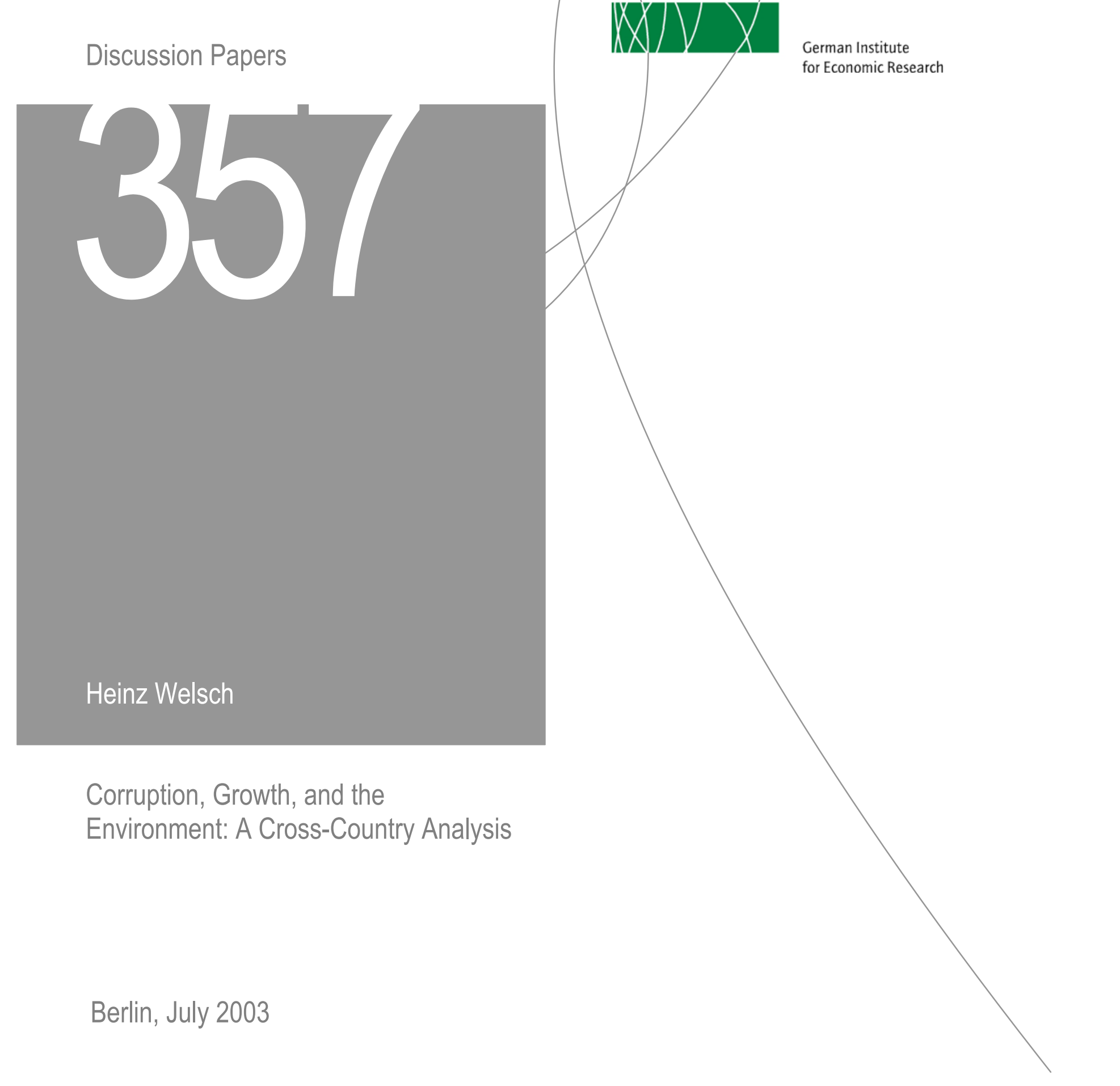


Opinions expressed in this paper are those of the author and do not necessarily reflect views of the Institute.

DIW Berlin

German Institute

for Economic Research

Königin-Luise-Str. 5

14195 Berlin,

Germany

Phone +49-30-897 89-0

Fax $\quad+49-30-89789-200$

www.diw.de

ISSN 1619-4535 


\title{
Corruption, Growth, and the Environment: A Cross-Country Analysis
}

\author{
Heinz Welsch \\ Department of Economics \\ University of Oldenburg \\ 26111 Oldenburg, Germany \\ Email: welsch@uni-oldenburg.de
}

November 2002

\begin{abstract}
The relationship between per capita income and a number of pollution indicators has been found to display an inverted U-shaped or downward-sloping pattern. Corruption may affect this relationship in two distinct ways: by raising pollution at given income levels (direct effect) and by reducing per capita income (indirect effect). The total effect is ambiguous a priori. Using cross section data for several indicators of pollution, the paper estimates the direct and the indirect effect of corruption on pollution. The indirect effect via income is positive or negative depending on the income level. If negative, the indirect effect is dominated by the positive direct effect. Overall, our measures of pollution are monotonically increasing in corruption. Because this relationship is particularly strong at low income levels, developing countries can considerably improve both their economic and environmental performance by reducing corruption.
\end{abstract}

Keywords: corruption, growth, pollution, environmental Kuznets curve JEL classification: Q2, K4, O1

Acknowledgements: Useful comment were received by Udo Ebert, Claudia Kemfert, Johann Graf Lambsdorff, Lutz Mommer, and two anonymous referees. 


\section{Introduction}

Corruption involves behavior on the part of public officials in which they unlawfully enrich themselves by the misuse of the power entrusted to them (Transparency International 2000). Corruption is not only a 'hot issue' in the public debate, but has also become an important field of economic research. While the literature started already in the $1970 \mathrm{~s}^{1}$, empirical research has begun to be undertaken only recently with the availability of data sets which allow the measurement of corruption levels across countries. ${ }^{2}$

Using cross-national data, corruption has been found to affect a variety of economic variables, such as total investment, GDP, government expenditure, capital flows and foreign direct investment, international trade, and foreign aid. ${ }^{3}$ In addition, case studies have suggested that corruption is an important source of environmental degradation, especially in developing countries (see, e.g., the contributions in Desai 1998), but systematic quantitative assessments of the environmental effects of corruption are only just starting to be undertaken.

What are the effects corruption may have on environmental pollution? The previous literature suggests that two partial effects can be distinguished. On the one hand, corruption may reduce the stringency of environmental regulation (Lopez and Mitra 2000, Damania et al. 2000) or the effectiveness with which environmental regulation is enforced (Hafner 1998, Lippe 1999), thus leading to higher pollution. On the other hand, corruption has been found to reduce prosperity (Mauro 1995, Hall and Jones 1999, Kaufmann et al. 1999) which, according to another strand of literature (Grossman and Krueger 1995, and others ${ }^{4}$ ), may lead to lower pollution at some income levels and to higher pollution at others. Therefore, the total effect of corruption on the environment cannot be determined a priori.

Given this background, the purpose of the present paper is twofold. In a first step it examines how corruption affects pollution at given levels of income, through corruption's effect on the formation and enforcement of environmental laws (direct effect). In a second step it investigates the influence of corruption on pollution via corruption's impact on income (indirect effect) and adds the indirect effect to the direct effect to obtain the total effect.

The relationship between prosperity and a number of indicators of environmental pollution follows what has come to be known as Environmental Kuznets Curve (EKC). The EKC entails that economic growth brings an initial phase of environmental deterioration followed

\footnotetext{
${ }^{1}$ Rose-Ackerman (1975) is the first published piece on the economics of corruption that received wide attention.

${ }^{2}$ Because acts of corruption are generally conducted in secrecy, corruption levels are difficult to measure. Recent empirical research has employed survey-based subjective indices on corruption which reflect the views of the international business community.

${ }^{3}$ For a review of empirical research see Lambsdorff (1999).

${ }^{4}$ See footnote 5 .
} 
by a subsequent phase of improvement. A frequent interpretation is that, as nations or regions attain higher income levels, their citizens demand that the non-material aspects of their standard of living be improved. The EKC is taken to be a reduced-form representation of these relationships (Grossman and Krueger 1995). A number of studies have supported the inverted U-shaped or even downward sloping income-pollution curve. ${ }^{5}$

The linkage between corruption and prosperity has been examined in a seminal paper by Mauro (1995) who found that corruption reduces economic growth. In terms of cross-national income levels, Hall and Jones (1999) found that per capita income is strongly linked to what they call social infrastructure, a construct which includes the degree to which a society is free from corruption. Exploring the issue in more detail, Kaufmann et al. (1999) found a strong negative association between corruption and per capita income.

In contrast to the income-pollution and the corruption-income linkages, systematic analysis of corruption-environment interactions has only just started. This line of research so far has focused on endogenizing the formation of environmental policy standards, using governmental corruption as one of the explanatory variables (see Damania et al. 2000, Fredriksson et al. 2002, and Fredriksson and Svenson 2002). In contrast to these papers, the present paper focuses on actual pollution and emission levels as the dependent variable. These actual levels do not depend on the stringency of environmental standards alone, but also on the effectiveness with which environmental law is being enforced, and this effectiveness of law enforcement is likely to vary inversely with corruption. ${ }^{6}$

To my knowledge this paper is the first to examine both the relationship between corruption and observed pollution levels at given levels of income (direct effect) as well as the influence of corruption on pollution via corruption's impact on income (indirect effect). Following most of the empirical literature on the economic effects of corruption, the paper uses cross-country regressions. This methodology is far from ideal due to unobserved heterogeneity across countries. It would clearly be preferable to turn to fixed-effect models with panels of data, but using such a methodology is prevented by the unavailability of panel data of corruption.

Using six indicators of ambient air and water pollution for 106 countries, the direct effect of corruption on pollution is found to be unambiguously positive, i.e. pollution-enhancing. The indirect effect via income may be positive or negative depending on the income level. Even if negative, the indirect effect is dominated by the direct effect, and the total effect of corruption

\footnotetext{
${ }^{5}$ In addition to Grossman and Krueger (1995), see Hilton and Levinson (1998), Holtz-Eakin and Selden (1995), Selden and Song (1994), Schmalensee, Stoker and Judson (1998), and Shafik (1994).

${ }^{6}$ The role of corruption in environmental policy formation is also investigated in a theoretical paper by Lopez and Mitra (2000). In contrast to the present paper, these papers neglect the indirect effect which corruption may have on the environment via corruption's effect on income.
} 
is to enhance pollution. Because the effect is particularly strong at low income levels, developing countries can considerably improve both their economic and environmental conditions by reducing corruption.

The paper is organized as follows. Section 2 discusses methodological issues, including the conceptual and empirical approach, and the data used. Section 3 examines the incomepollution relationship and the (direct) corruption-pollution relationship, taking income as exogenous. Section 4 introduces the corruption-income relationship and examines the total effect of corruption on pollution, as well as its composition in terms of the two partial effects described above. Section 5 concludes.

\section{Methodological Approach and Data}

\section{a) Framework of Analysis}

The popular notion that environmental quality deteriorates steadily with economic growth has been called into question in a number of studies. As mentioned above, recent empirical evidence for a number of environmental indicators suggests that economic growth may possibly bring initial environmental deterioration which is then followed by a subsequent phase of improvement, a relationship referred to as Environmental Kuznets Curve (EKC).

The inverse relationship between income and pollution at higher income levels is mostly explained in terms of an induced policy response, in the sense that people demand stricter environmental standards as per capita incomes rise (see, e.g., OECD 1991). This idea is formalized by Antweiler et al. (2001). In their model, optimal environmental regulation becomes stricter as income rises, leading to lower pollution intensity of income (technique effect). On the other hand, rising income implies a larger scale of economic activity. Whether rising income increases or reduces pollution, then, depends on the relative strength of the scale versus technique effects, which will typically vary with the income level.

Even if optimal environmental standards become stricter as income rises, the desire for stricter environmental regulation will translate into actual environmental policy only if citizens are able to express their preferences for environmental quality and if governments have an incentive to satisfy these preferences by changing policy. Based on this line of reasoning, Barrett and Graddy (2000) found that an increase in civil and political freedoms significantly improves environmental quality. In a related fashion, environmental policy formation is also affected by rent-seeking and corruption (Lopez and Mitra 2000, Damania et al. 2000). In addition, corruption may impact on pollution not only via the formation of 
environmental laws, but also through the strictness with which these laws are enforced (Hafner 1998, Lippe 1999).

These considerations suggest that pollution varies not only with income, but also with the degree of corruption at any given level of income. This, then, gives rise to an extended EKC, which can be written as follows:

$$
p=f(y, c)
$$

where $p=$ pollution, $y=$ per capita income, $c=$ corruption level.

It follows from the literature discussed above that the partial derivative $\partial p / \partial c$ is expected to be positive, reflecting the adverse impact of corruption on the formation and enforcement of environmental laws. ${ }^{7}$ If $\partial p / \partial c$ were restricted to zero, equation (1) would capture the usual EKC relationship. According to the EKC literature (see footnote 5), the sign of $\partial p / \partial y$ is ambiguous but likely to be negative at higher income levels.

In the empirical specification of equation (1) we will closely follow Grossman and Krueger (1995), hereafter referred to as G-K, which is a standard in this literature (see section 2d). Estimation of equation (1) will be the first step in our analysis of the corruption-pollution relationship.

In addition to the direct effect of corruption on pollution, as captured by (1), there exists an indirect channel through which corruption can affect pollution, as corruption has been found to adversely affect per capita income. In formulating the relationship between corruption and per capita income we follow Hall and Jones (1999), who base their analysis on a standard production function framework. Assuming that output (income) is a function of physical capital, human capital, and total factor productivity, and that this production function is linear homogeneous in the first two arguments, income per person depends on physical and human capital per person, and on productivity. Hall and Jones (1999) found that cross-country differences in productivity are significantly driven by differences in what they call social infrastructure, which includes the degree to which a society is free from corruption.

Based on this framework of analysis we obtain the following corruption-income relationship:

$$
y=g(k, h, c)
$$

\footnotetext{
${ }^{7}$ It should be noted that the positive corruption-pollution relationship refers to actual pollution. In addition, there may exist a downward bias in reported emissions, and this bias may be reasonably assumed to increase in the corruption level. This would induce a negative linkage between corruption and reported emissions at given actual emission levels. We will return to this issue later.
} 
where $k$ and $h$ denote physical and human capital per person, respectively. ${ }^{8}$ In line with Hall and Jones (1999) as well as Kaufmann et al. (1999) we expect $\partial y / \partial c$ to be negative.

Estimating equation (2) is the second step in our empirical analysis, leading to the identification of the indirect effect of corruption on pollution and contributing to the derivation of the total effect.

Given the partial effects, the total effect of corruption on pollution can be decomposed as follows:

$$
\frac{d p}{d c}=\frac{\partial p}{\partial y} \frac{\partial y}{\partial c}+\frac{\partial p}{\partial c}
$$

In this formula, the rightmost expression represents the direct effect, which relates to the impact of corruption on the formation and enforcement of environmental law. The first expression on the right-hand side is the indirect effect via corruption's impact on prosperity.

\section{b) Indicators of Pollution}

Following much of the literature mentioned in footnote 5, we consider indicators of both air and water pollution. As far as the choice between ambient pollutant concentrations and pollution emission levels is concerned, one could argue that emission data should be used because emissions are more closely linked to both economic activity levels and corrupt practices than is ambient pollution. On the other hand, ambient pollution rather than emissions is what citizens will have preferences over, and what they will possibly demand to be restricted as prosperity rises. To avoid needless controversy on this issue we will use ambient pollution data as well as data on pollution emissions and environmental stresses in our analysis. ${ }^{9}$

The pollution indicators employed are listed in rows 1 through 12 of Table 1 . The first six indicators refer directly to air and water quality, the others to environmental emissions or

\footnotetext{
${ }^{8}$ It should be noted that this approach shares some common elements with the empirical growth literature associated with Barro (1991) and others. In the empirical specification (section 2d) we will refer to this literature especially with respect to the choice of proxies for human capital. Nevertheless, the current framework differs fundamentally in its focus on levels instead of rates of growth. There are several reasons why this focus is important in its own right (see Hall and Jones 1999). In the current context this focus is the result of our research objective.

9 Another issue involved in the choice between ambient pollutant concentrations and emission levels is the reliability of the data, an aspect to which we will return later.
} 
stresses. ${ }^{10}$ In addition to the pollution indicators, we use data on per capita income, physical and human capital, and corruption levels, also listed in Table 1.

Table 1: List of Variables

\begin{tabular}{|l|l|l|}
\hline 1 & SO2 & Urban sulphur dioxide concentration \\
\hline 2 & NO2 & Urban nitrogen dioxide concentration \\
\hline 3 & TSP & Urban total suspended particulate concentration \\
\hline 4 & GMS_DO & Dissolved oxygen demand \\
\hline 5 & GMS_PH & Phosphorus concentration \\
\hline 6 & GMS_SS & Suspended solids \\
\hline 7 & SO2KM & Sulphur dioxide emissions per populated land area \\
\hline 8 & NOXKM & Nitrogen oxide emissions per populated land area \\
\hline 9 & VOCKM & Volatile organic compound emissions per populated land area \\
\hline 10 & FERTHA & Fertilizer consumption per hectare of arable land \\
\hline 11 & PESTHA & Pesticide use per hectare of crop land \\
\hline 12 & BODWAT & Industrial organic pollutants per available freshwater \\
\hline 13 & GNPPC & GNP per person \\
\hline 14 & CAPPC & Physical capital per person \\
\hline 15 & ADLIT & Adult literacy rate \\
\hline 16 & RDPERS & Scientists and engineers per population \\
\hline 17 & CORR & Corruption measure \\
\hline
\end{tabular}

The pollution indicators (1) - (3) refer to ambient air quality. Their major anthropogenic sources include the combustion of fossil fuels in electricity generation, certain chemical and industrial processes, home heating, and car traffic.

The indicators (4) - (6) measure water quality. Increasing dissolved oxygen demand (or likewise decreasing dissolved oxygen concentration) indicates contamination by organic carbon contained in sewage, industrial discharges, or the runoff from agricultural areas. Phosphorus concentration is mainly related to fertilizer use in agriculture, whereas suspended solids stem from agriculture, mining, and industry (including refineries).

The emissions of air pollutants (7) - (9) and water pollutants (10) - (12) are the stresses which cause environmental degradation as measured by the ambient pollution indicators (1) - (6).

\footnotetext{
${ }^{10}$ These are the major indicators of environmental quality and environmental stresses identified and compiled in the Environmental Sustainability Index initiative (see WEF/YCELP/CIESIN 2001).
} 
Sulphur dioxide and nitrogen oxides result from fuel combustion. Major sources of volatile organic compounds include car traffic, fuel distribution, and refineries. The use of fertilizers and pesticides is, of course, related to agriculture whereas industrial organic pollutants refer to industrial discharges.

Given that the various types of ambient pollution and emissions predominantly originate from different sectors of the economy, the sectoral economic structure of a particular country can be expected to have an impact on its pollution profile. In addition, the income-pollution relationship of countries in which resource rents (especially from oil and gas) represent a major fraction of national income may be different from that of other countries. We will attempt to capture such influences, at least in a tentative way, by using country dummies.

\section{c) Sources and Description of Data}

The pollution indicators (1)-(12) listed in Table 1 have been assembled for 122 countries in the context of an effort to construct a global Environmental Sustainability Index (ESI). For a detailed description of the original data, their sources, and the way in which the final data base was prepared see WEF/YCELP/CIESIN (2001).

The ESI air quality indicators (1)-(3) are from the World Health Organization's Air Management Information System (AMIS) and refer to the most recent year available (MRYA) within the time period of 1990-96. The water quality indicators (4)-(6) are based on data from the United Nations Environment Programme's Global Environmental Monitoring System (GEMS) and are averages over 1994-96 or MRYA. The air pollution emission indicators (7)(9) are based on data from the Emission Database for Global Atmospheric Research (EDGAR) of the Netherlands National Institute for Public Health and Environment (RIVM) and refer to 1990. Fertilizer use (10) and industrial organic pollutants (12) are taken from the World Bank's World Development Indicators 2000 for 1997 and 1996 respectively, and pesticide use (11) comes from the World Resources Institute's World Resources 2000-2001 for 1996. A major difference between the data on emissions and environmental stresses (7) (12) and the ambient pollution data (1) - (6) is that the former have been compiled from national sources whereas the latter come from international monitoring programs.

The data on scientists and engineers (16) ${ }^{11}$ and corruption levels (17) are also from the ESI databank. The former refer to the MRYA within the period 1980-97 and are based on the

\footnotetext{
${ }^{11}$ This variable, jointly with the adult literacy rate (15), will serve as a proxy for human capital per person in equation (2). A discussion of this choice of proxies is provided in section $2 \mathrm{~d}$.
} 
UNESCO's Statistical Yearbook 1999. Corruption levels are from the World Bank (see Kaufmann et al. 2000) ${ }^{12}$ and refer to $2000 .^{13}$

The final data included in the ESI and used in this paper take the form of $Z$ scores, i.e. deviations of individual values from their mean, divided by the standard deviation. A $Z$ score equal to zero indicates the mean for the 122 countries, a $Z$ score equal to +1.5 or -1.5 respectively represents 1.5 standard deviations above and below the mean, and so on. Since the ESI indicators have been constructed such as to correspond to high levels of environmental sustainability, we multiplied them by minus 1 to obtain indicators of pollution. GNP per capita (13) and adult literacy rates (15) were taken directly from the World Development Report and refer to 1994 and 1995 respectively. These reference years were chosen so as to achieve the best possible correspondence with the pollution indicators. The GNP data are PPP estimates and are in current international \$. The literacy rates are in percent. $^{14}$

Physical capital per person (14) is taken from the data base underlying Hall and Jones $(1999)^{15}$ and is expressed in $\$$.

The summary statistics of the data used are summarized in Table A1 in the Appendix. Their correlations are shown in Table A2 of the Appendix. One striking feature of the data is the lack of correlation between $\mathrm{NO}_{\mathrm{X}}$ emissions (NOXKM) and urban $\mathrm{NO}_{2}$ concentrations (NO2). With respect to $\mathrm{SO}_{2}$ emissions ( $\mathrm{SO} 2 \mathrm{KM}$ ) and corresponding urban concentrations (SO2) the correlation is even slightly negative $(-0.17)$. On the other hand, there is a rather high negative correlation (-0.88) between per capita income (GNPPC) and corruption (CORR).

\section{d) Procedure of Empirical Analysis}

In section 3 we will examine the relationship between per capita income and pollution as well as between corruption and pollution, taking income to be exogenous. In other words, we will estimate the extended EKC, equation (1), disregarding equation (2). Following G-K, which is a standard in this literature, the income-pollution relationship will be specified as a cubic

\footnotetext{
${ }^{12}$ This data set comprises subjective indices on corruption. One way of constructing such indices is to ask business people to provide an estimate of the kickback per deal (as a percentage of the deal's value) that would have to be paid in order to conduct business in each country. Similar data sets have originaly been developed to determine country ratings to be used by banks, institutional investors, or multi-national firms. Subjective corruption data thus are the market's choice of a corruption indicator. They are preferred over hard data, such as numbers of convictions for corruption, because the latter cannot capture undiscovered corruption cases and are of low international comparability.

${ }^{13}$ Because cross-country corruption profiles may not be expected to change quickly, using data for 2000 seems to be appropriate for our purposes.

${ }^{14} \mathrm{We}$ did not transform these data into $Z$ scores because, in contrast to the pollution indicators, the original units of GNP and literacy can be easily interpreted.

${ }^{15} \mathrm{See}$ http://emlab.berkeley.edu/users/chad/HallJones400.asc.
} 
function. This provides a sufficiently flexible form which imposes no specific shape on the income-pollution relationship, without being overly demanding given the data limitations. ${ }^{16}$ To account for possible peculiarities in economic structure, we will experiment with a dummy variable for OPEC countries. Corruption will be included in linear form. ${ }^{17}$

The general form of the equations to be estimated is:

$$
P_{i j}=\alpha_{i 0}+\alpha_{i 1} G N P P C_{j}+\alpha_{i 2} G N P P C_{j}^{2}+\alpha_{i 3} G N P P C_{j}^{3}+\alpha_{i 4} O P E C_{j}+\alpha_{i 5} C O R R_{j}+u_{i j}
$$

where the subscript $i$ refers to the pollutant and the subscript $j$ to the country. In section 3 we will estimate these equations separately for each pollutant, using ordinary least squares. ${ }^{18}$ This serves mainly to identify preferred specifications of the way in which corruption may intermediate between income and pollution.

Having selected preferred specifications for the income-pollution and corruption-pollution relationships, section 4 moves on to examine the corruption-income relationship, equation (2). As discussed in section $2 \mathrm{a}$, our formulation is based on a production function framework along similar lines as Hall and Jones (1999). In spite of our focus on levels instead of growth rates (cf. footnote 8) our choice of proxies for human capital per person is informed by the empirical literature on economic growth. According to this literature, desirable properties of human capital proxies are that they should refer to stocks (not to flows, such as school enrolment rates or numbers of scientific and technical articles) and that they should reflect the convexity of the human capital construct in educational attainment levels (Barro and Sala-iMartin 1995). These requirements are satisfied by using the adult literacy rate (ADLIT) and the population share of scientists and engineers (RDPERS) as human capital proxies. ${ }^{19}$

We estimate a linearized version of equation (2). The reason for this simple approach is the lack of a compelling theoretical basis for deriving a specific way in which corruption affects

\footnotetext{
${ }^{16}$ It should be noted that there exists a strong multicollinearity between the first, second and third powers of GNPPC. As will be discussed in section 3a, this makes it difficult in some cases to infer much about the individual coefficients of the powers of GNPPC. This problem would be aggravated by attempting more flexibility through the use of higher powers.

${ }^{17}$ A sensitivity analysis using in addition the second power of CORR will be discussed in section $4 \mathrm{~d}$. Of course, one might explore alternative specifications, such as including income-corruption interactive terms. However, the aim of this paper with respect to the EKC is modest. We only want to determine whether corruption can be shown to intermediate between income and pollution. If the link does exist, it should show up in our model; and if our model can show this while making only the smallest deviation from the previous literature, so much the better. For similar reasoning with respect to the freedom-pollution relationship see Barrett and Graddy (2000).

${ }^{18} \mathrm{G}-\mathrm{K}$ also consider each pollutant separately. However, since they have a panel of data at their disposal, they use a random-effects generalized least squares estimator.

19 Adult literacy rates have been found theoretically attractive and empirically significant in the growth regressions of Barro (1991). Science and technology have likely become increasingly important since the mid 1980 s, which represent the typical terminal period in the growth regression literature.
} 
income. Especially, it isn't obvious how corruption should be interacted with the various capital variables (physical and human). In such a case of vagueness any attempt at richer specification would be ad hoc. We therefore choose to enter the explanatory variables independently and linearly in order to let the data identify a possible link between corruption and income without imposing any particular interaction structure. ${ }^{20}$ To control for resource rents as a possible intermediating variable, we include OPEC membership.

The estimated equation is of the following form ${ }^{21}$ :

$$
\mathrm{GNPPC}_{j}=\beta_{0}+\beta_{l} C A P P C+\beta_{2} A D L I T_{j}+\beta_{3} R D P E R S_{j}+\beta_{4} O P E C_{j}+\beta_{5} C O R R_{j}+v_{j}
$$

After least-squares estimation of equation (5), the system of equations (4) and (5) is estimated simultaneously for an appropriate subset of pollutant indicators.

\section{Impacts of Income and Corruption on Pollution}

\section{a) The Income-Pollution Relationship}

Estimates of equation (4) for the twelve pollution indicators discussed in section $2 b$ are displayed in Table A3 in the Appendix. The regressions control for heteroskedasticity using White's method.

We first consider the 'conventional' cubic income-pollution relationship (REG 1). In view of the strong multicollinearity among the powers of per capita income, it is in some cases difficult to infer much about their individual coefficients (see the discussion of the curves below). However, as indicated by the $p$-values, the collection of income, income-squared and income-cubed is in most cases highly significant as a determinant of air and water pollution. ${ }^{22}$ If we augment this relationship by the dummy variable for OPEC membership (REG 2), we find that this variable is significant at the five percent level in five out of our twelve cases. Significant positive coefficients are found for dissolved oxygen demand, suspended solids, and volatile organic carbon emissions. These effects probably reflect the importance of the

\footnotetext{
${ }^{20}$ Linear regressions are used in virtually all of the empirical literature on the economic effects of corruption, for the same reasons as discussed above. The robustness with respect to including in addition the second power of corruption is discussed in section $4 \mathrm{~d}$.

${ }^{21}$ The issue of potential endogeneity of corruption is not explicitly addressed in this paper, because it would be difficult to find an instrumental variable for corruption for the set of countries considered here. However, application of instrumental variable techniques by Hall and Jones (1999) and Kaufmann et al. (1999) to the relationship between cooruption and GDP per capita strongly suggests causality from the former to the latter.

${ }^{22}$ In their seminal paper, G-K report similar findings. In nine out of the twelve cases considered here, the probability of all powers of per capita income being jointly insignificant (p-value) is less than 0.0001 . The three cases in which the influence of income is ambiguous refer to NO2, GMS_PH and BODWAT.
} 
refinery industry in these countries. The negative coefficient for $\mathrm{SO}_{2}$ emissions might be related to low heating requirements and the relative unimportance of heavy industry, whereas the negative coefficient in the case of pesticide use reflects the low importance of large-scale agriculture.

The income-pollution curves that emerge from REG 1 or REG 2 are plotted in Figure 1 (ambient pollution) and Figure 2 (environmental emissions and stresses). For those pollutants which are examined in both the G-K and the present paper $\left(\mathrm{SO}_{2}\right.$, particles, dissolved oxygen), the visual shape of the respective curves is almost identical. ${ }^{23}$ This is all the more surprising because the two papers use different data bases and different estimation methods. ${ }^{24}$ It lends strong support to the robustness of these estimates.

With respect to ambient pollution we find an inverted U-shaped pattern in the cases of $\mathrm{SO}_{2}$ and $\mathrm{NO}_{2}$ over large portions of the income scale. Even though the estimated relationships turn up again at very high levels of income, we cannot have much confidence in the shape of the curves in this range because of the relatively small number of observations for countries with income above $17000 \$$. It must be conceded, however, that the curve for $\mathrm{NO}_{2}$ is rather flat, which reflects the fragility of this relationship already noted in footnote 22 . The same qualification applies to phosphorus. In contrast to these two cases, the inverted U-shape of the $\mathrm{SO}_{2}$ curve in the relevant range is quite reliable (see the t-statistics shown in Table A3).

For total suspended particulates we find a monotonically decreasing relationship at all levels of income. In the case of dissolved oxygen and suspended solids, the relationship is decreasing up to an income level of $21000 \$$ and $19000 \$$ respectively. Here again, not much confidence should be placed in the shape of the curves at these income levels because of the small number of observations. The declining shape of these three curves, at least in the relevant income range, is quite reliable since in the underlying regressions GNPPC has a significant negative coefficient, whereas the second and third powers are insignificant (see Table A3).

\footnotetext{
${ }^{23}$ It should be noted that G-K consider dissolved oxygen concentration, rather than dissolved oxygen demand, the former being an indicator of high rather than low water quality.

${ }^{24}$ G-K use panel data from the 1980s, taken from 42 countries (air) or 58 countries (water) and employ a random-effects generalized least squares estimator to account for unobserved heterogeneity across their observational units. The cross-section data used in the present paper do not permit such an approach.
} 
Figure 1: Relationship between Per Capita Income and Ambient Pollution
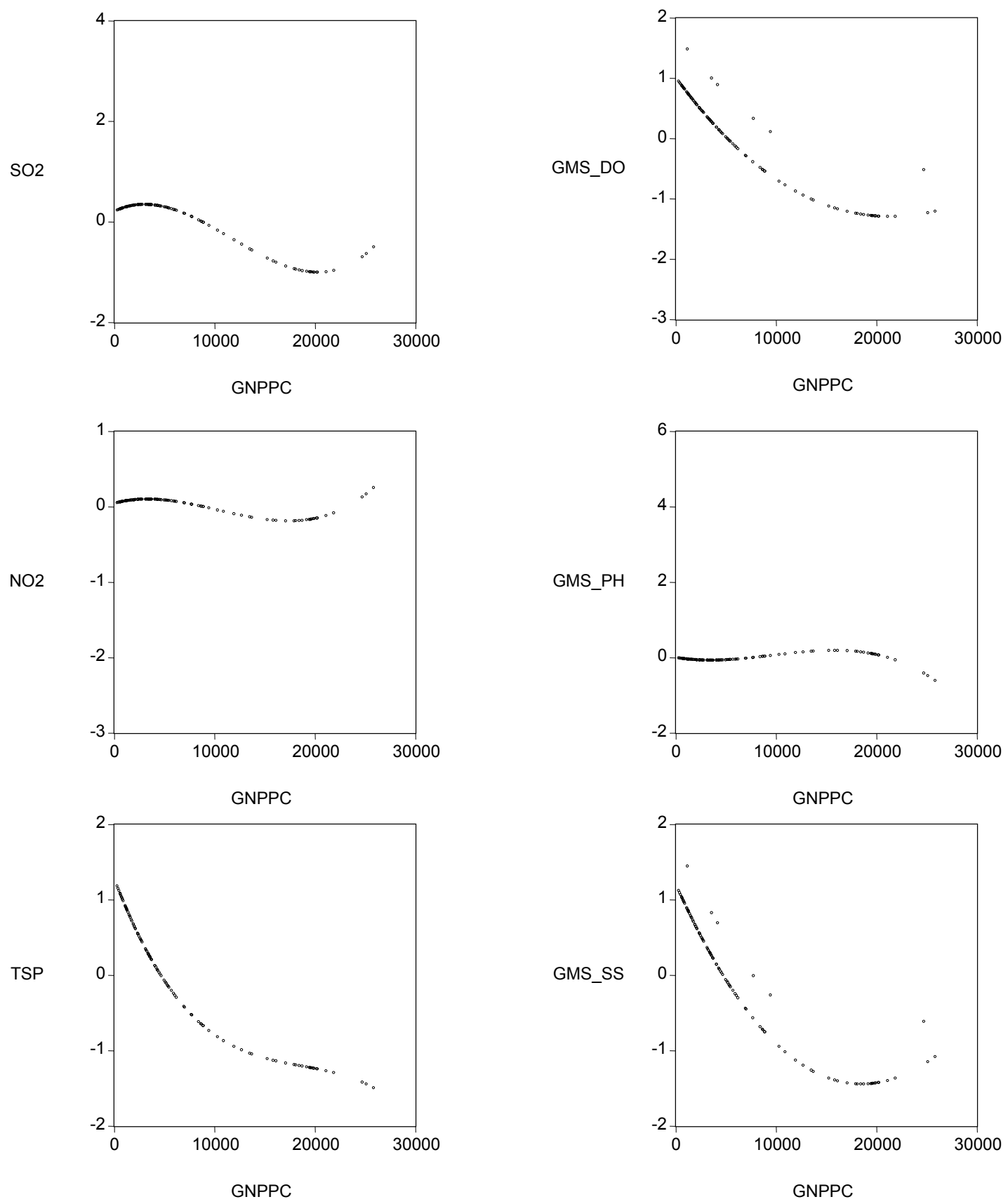

With respect to environmental stresses (Figure 2), we find a very flat relationship between income and BODWAT (industrial organic pollutants), which, again, reflects the ambiguity already noted in footnote 22 . For the other types of pollutants, the various powers of income are jointly significant determinants of emissions. Even though the estimates suggest the existence of an interior maximum in all six cases, it is striking that the peaks appear to occur at much higher income levels than in the case of ambient pollution. 
Figure 2: Relationship between Per Capita Income and Emissions/Environmental Stresses
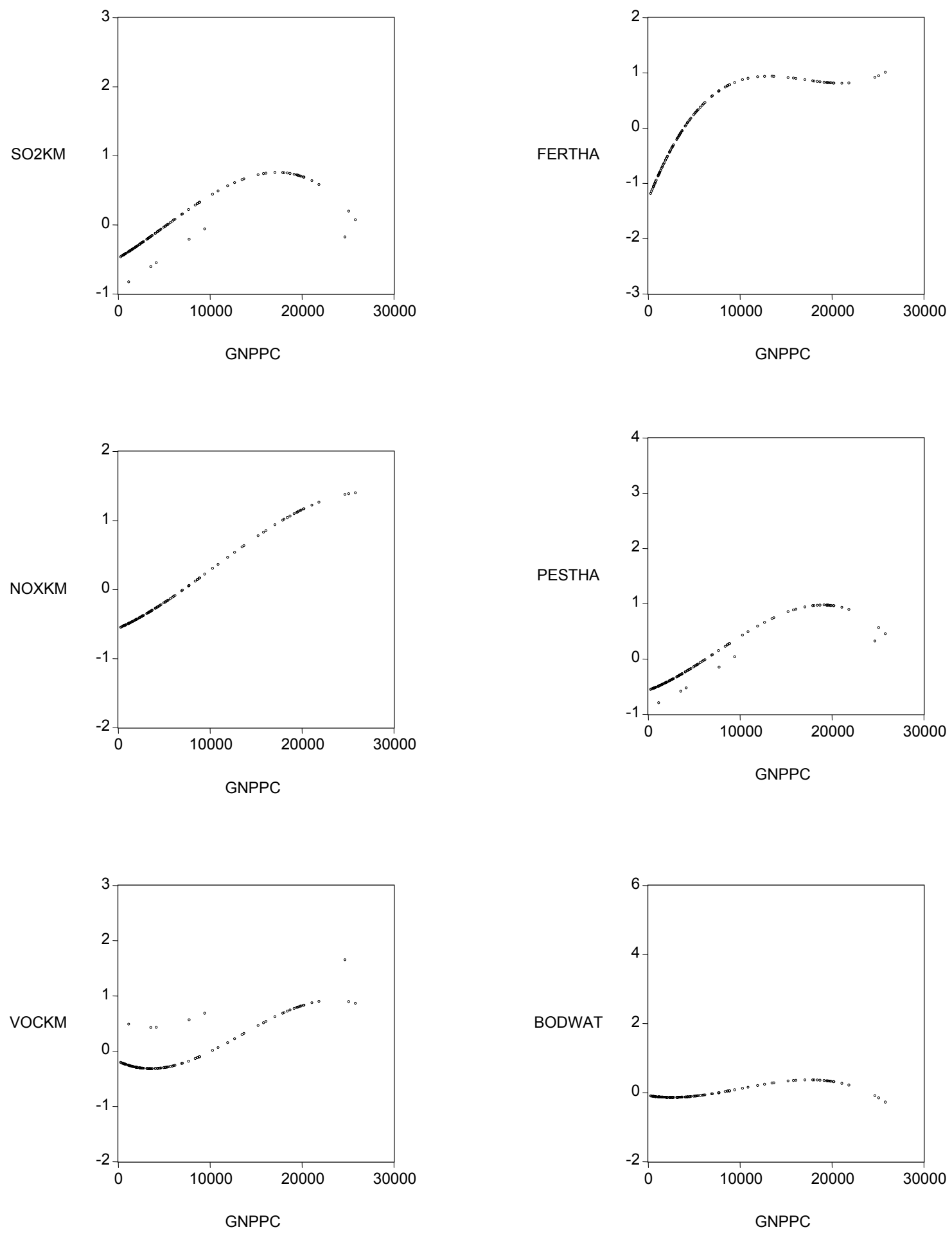
The visual impressions are confirmed when examining the computed per capita income levels at which pollution levels attain their maximum (Table 2). In spite of differences in the data and estimation methods (see footnote 24), it is instructive to compare our results with those of G-K. For total suspended particles both studies find a decreasing income-pollution relationship. For sulphur dioxide, our peak-income estimate is one fourth below that of G-K. ${ }^{25}$ The income levels at which the $\mathrm{SO}_{2}$ and $\mathrm{NO}_{2}$ concentrations peak roughly correspond to the income of Sri Lanka and Guatemala, respectively.

Table 2: Estimated Income at Peak Pollution Level (\$ per capita)

\begin{tabular}{|l|l|l|l|}
\hline SO2 concentration & 3068 & SO2 emissions & 20259 \\
\hline NO2 concentration & 3355 & NOX emissions & 27154 \\
\hline TSP concentration $^{\mathrm{a}}$ & 0 & VOC emissions & 23531 \\
\hline Dissolved oxygen demand $^{\mathrm{a}}$ & 0 & Fertilizer use & 13205 \\
\hline Phosphorus concentration & 15840 & Pesticide use & 19104 \\
\hline Suspended solids & 0 & Industrial organic pollutants & 17601 \\
\hline Ambient air pollution $^{\mathrm{b}}$ & 2141 & Air pollutant emissions & \\
\hline Ambient water pollution $^{\mathrm{b}}$ & 5280 & Stresses on water quality & 23648 \\
\hline
\end{tabular}

${ }^{\mathrm{a}}$ Because the curves for total suspended particulates, dissolved oxygen demand, and suspended solids are decreasing over the relevant range, the respective income levels were set to zero. ${ }^{b}$ Unweighted average.

Comparing our results for ambient pollution with those for emissions and stresses, a striking result is that for sulphur dioxide the peak of emissions occurs at an income 6.6 times that at which ambient pollution has its maximum. For nitrogen oxides the corresponding income levels differ by a factor of $8.1{ }^{26}$ Similar discrepancies occur with respect to the averages for air and water, respectively.

It is puzzling that emission levels should keep rising at income levels at which the corresponding ambient pollution has long exceeded its peak (viz. especially $\mathrm{SO}_{2}$ and $\mathrm{NO}_{2}$ ). $\mathrm{A}$ speculation which might resolve this puzzle would entail that the emissions data are less reliable than are the ambient pollution data, the former being downward biased in low-income countries. Considering that the emissions data come largely from national sources, whereas the ambient pollution data come from international monitoring programs, the idea of reported emissions being biased downward is not implausible. That this bias might be larger at lower

\footnotetext{
${ }^{25}$ The G-K study refers to the 1980s, whereas our data refer to the mid 1990s. Technology, especially the fuel efficiency of power stations, has improved worldwide in the meantime, irrespective of income levels. (Note that using $\mathrm{Z}$ scores to measure pollution does not affect the income levels at which pollution levels peak.)
} 
incomes would be consistent with the inverse relationship between income and corruption, to be considered below. We will get back to this issue immediately.

\section{b) The Corruption-Pollution Relationship}

If we augment the previous regressions by the level of corruption (REG 3 and REG 4 in Table A3, see Appendix), we find that this regressor is positive and significant at a 5 percent confidence level for most indicators of ambient pollution; it is positive and significant at a 10 percent level for all ambient pollution indicators except phosphorus in river basins. In contrast to ambient pollution, corruption is insignificant for all types of emissions and environmental stresses, with uneven signs.

The almost unanimous significance of the corruption variable with respect to ambient pollution is remarkable in view of the strong correlation between corruption and income discussed in section $2 \mathrm{c}$. It should also be noted that the inclusion of the corruption variable strongly improves the explanatory power of the respective regressions ( $R$-squared and $p$ value).

The ambiguous and insignificant estimates in the case of emissions support the conjecture formulated above that reported emissions (in contrast to ambient pollution) could be below their actual levels and that the bias is an increasing function of corruption. In this case, inference about the likely positive effect of corruption on emissions via reduced stringency and enforcement of environmental laws would be obscured by the negative impact of corruption on the reporting of emissions.

These doubts about the appropriateness of the environmental emissions/stresses data for our purposes suggest to drop environmental emissions and stresses from the subsequent analysis. The remainder of the paper will therefore focus on ambient pollution.

In contrast to the 'conventional' income-pollution relationship discussed in the preceding section, the OPEC variable always turns out to be insignificant once corruption is introduced as a regressor in the ambient pollution equations. ${ }^{27}$ Therefore we select that version of equation (4) in which the coefficient on OPEC is restricted to zero (REG 3) as the unanimously preferred specification to capture the effect on ambient pollution of income and corruption. In this specification, corruption is significant at least at the 5.5 percent level for all ambient pollution indicators except phosphorus.

The general result based on this preferred specification is that reducing corruption by one standard deviation (SD) would reduce ambient pollution levels by $0.25 \mathrm{SD}$ (VOC) to $0.45 \mathrm{SD}$

\footnotetext{
${ }^{26}$ The income level at which $\mathrm{NO}_{\mathrm{X}}$ emissions peak is actually out of the sample income range.
} 
(suspended solids in rivers). ${ }^{28}$ In any case, corruption does affect pollution at given income levels.

To see whether the inclusion of the corruption variable affects the previous conclusions concerning the income-pollution relationship, Figure 3 plots the estimated pollution levels based on our preferred specification against per capita income. The general shape of the income-pollution relationships is similar to Figure 1, but a given income level may now be associated with different levels of pollution, due to the influence of corruption. For $\mathrm{SO}_{2}$ and particles, the two pollutants which are also covered in the study of Barrett and Graddy (2000) on the influence of political freedoms, our pictures look very similar to theirs.

An interesting question is how the inclusion of corruption affects the per capita income levels at which pollution levels attain their maximum. These income levels are shown in Table 3. In comparison with Table 2 we find that the income at which the $\mathrm{SO}_{2}$ concentration in urban air and the phosphorus concentration in rivers peak is now substantially higher, whereas it gets reduced to zero for $\mathrm{NO}_{2}$.

The result for $\mathrm{SO}_{2}$ and phosphorus can be explained in terms of the following logic. Because, as we shall see, higher income goes along with lower corruption, omission of the corruption variable from the income-pollution relationship entails that the pollution-reducing effect of lower corruption is partly attributed to income. The pollution-reducing effect of higher income therefore starts at lower income levels than in the case where corruption is explicitly included.

\footnotetext{
${ }^{27}$ This suggests that the OPEC variable may have acted as a proxy for corruption.

${ }^{28}$ We will get back to the (direct) impact of corruption on pollution as discussed above in section $3 \mathrm{~b}$, where results based on estimating the pollution equations jointly with the corruption-income relationship are presented.
} 
Figure 3: Income-Pollution Relationship when Corruption is Included
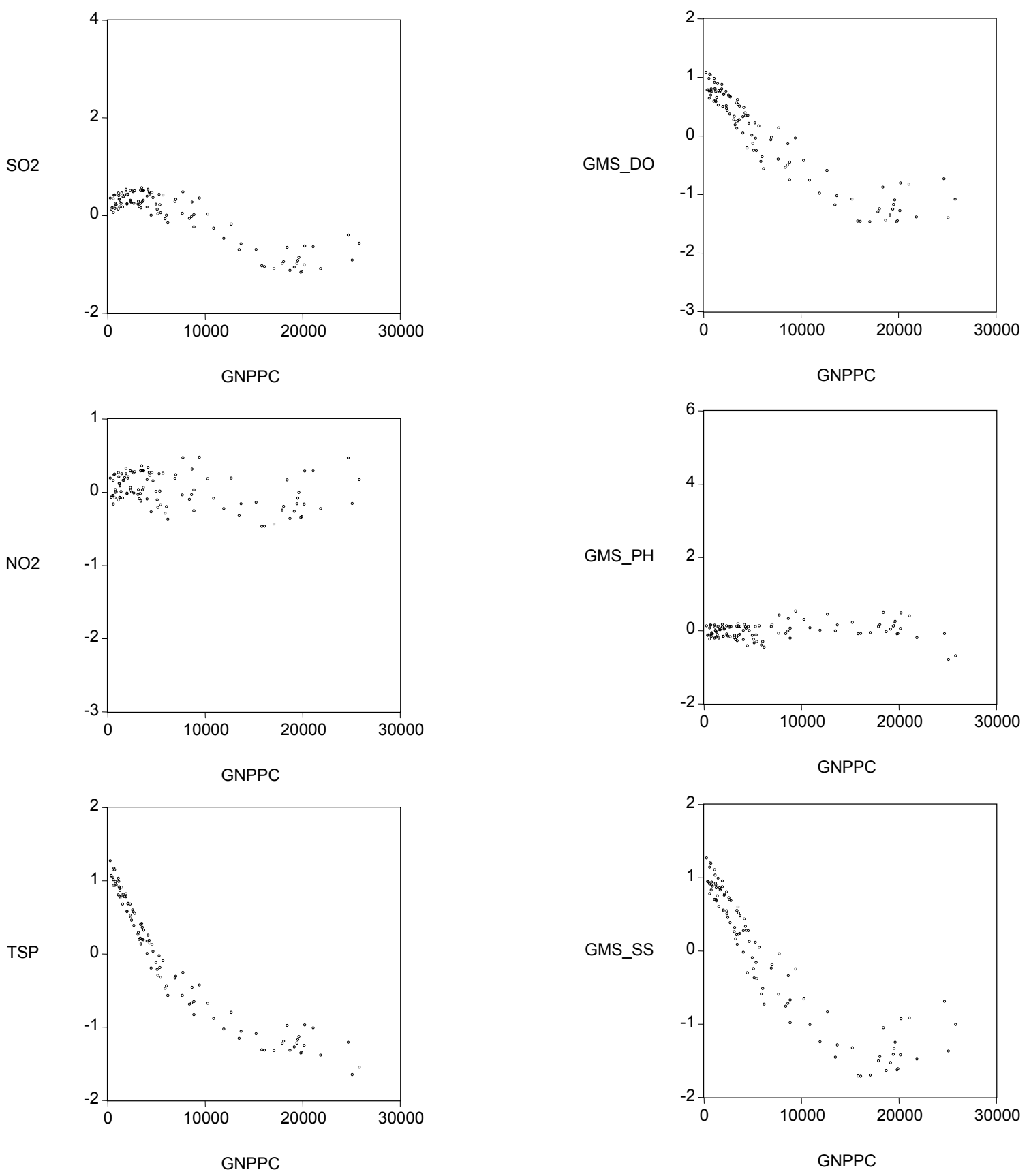
Up to this point, the dependence of income on corruption and the implied indirect effect of corruption on pollution were ignored. These issues will now be addressed.

Table 3: Estimated Income at Peak Pollution Level When Corruption is Included (\$ per capita)

\begin{tabular}{|l|l|l|l|}
\hline SO2 concentration & 5586 & Dissolved oxygen demand & 0 \\
\hline NO2 concentration & 0 & Phosphorus concentration & 17942 \\
\hline TSP concentration & 0 & Suspended solids & 0 \\
\hline Ambient air pollution $^{\text {a }}$ & 1862 & Ambient water pollution & 5981 \\
\hline
\end{tabular}

${ }^{\mathrm{a}}$ Unweighted average

\section{Total Impact of Corruption on Pollution}

\section{a) The Corruption-Income Relationship}

Table 4 shows our basic evidence on the relationship between corruption and per capita income. We control for heteroskedasticity so that t-statistics in parenthesis are White corrected.

REG 1 presents our standard set of explanatory variables: physical capital per person and human capital per person, the latter being proxied by the adult literacy rate and the percentage of scientists and engineers. ${ }^{29}$ Physical capital as well as the human capital proxies affect income positively and significantly. They jointly account for a substantial portion of the dispersion of per capita income across countries, as measured by $R$-squared. REG 2 introduces OPEC membership as an additional explanatory variable and finds it insignificant, leaving the other regressors almost unaffected.

REG 3 and REG 4 introduce the corruption level to the list of regressors. In both cases, $R$ squared is increased by about 0.06 , in comparison with REG 1 and REG 2, respectively. In REG 3, corruption affects per capita income negatively and significantly. As shown in REG 4, OPEC membership is again insignificant. ${ }^{30}$

\footnotetext{
${ }^{29}$ Due to the public-good characteristics of knowledge, per capita income can be expected to depend also on worldwide research and development. In our regressions, such an influence is captured by the intercept.

${ }^{30}$ The coefficient in REG 4 is positive, while it is negative in REG 2 where it may have acted as a proxy for corruption.
} 
Table 4: Income Regression (Dependent variable: GNPPC. Method: OLS)

\begin{tabular}{|l|c|c|c|c|}
\hline & REG 1 & REG 2 & REG 3 & REG 4 \\
\hline CONST & 1966.651 & 1920.468 & 2612.875 & 2651.353 \\
& $(2.88)$ & $(2.82)$ & $(3.65)$ & $(3.44)$ \\
\hline CAPPC & 0.155 & 0.157 & 0.133 & 0.131 \\
& $(9.29)$ & $(9.43)$ & $(5.89)$ & $(5.35)$ \\
\hline ADLIT & 20.209 & 20.782 & 17.350 & 17.065 \\
& $(1.99)$ & $(2.03)$ & $(1.84)$ & $(1.79)$ \\
\hline RDPERS & 1983.036 & 1912.991 & 1617.839 & 1625.971 \\
& $(4.17)$ & $(4.03)$ & $(3.06)$ & $(3.02)$ \\
\hline OPEC & & -768.850 & & 238.912 \\
& & $(1.36)$ & & $(0.34)$ \\
\hline CORR & & & -1166.772 & -1210.338 \\
& & & $(2.09)$ & $(1.92)$ \\
\hline R2 & 0.925 & 0.925 & 0.931 & 0.931 \\
\hline Adjusted R2 & 0.922 & 0.921 & 0.927 & 0.927 \\
\hline
\end{tabular}

Note: t-statistics in parenthesis are White-corrected.

Our general assessment of the regressions shown in Table 4 is that corruption plays a significant negative role in explaining differences in per capita income across countries. Since OPEC membership is insignificant, we select REG 3 as our preferred specification of the corruption-income relationship. ${ }^{31}$ According to this specification, a one standard deviation increase in corruption reduces per capita income by $1167 \$ .^{32}$ The effect of corruption on income is about three times the effect of adult literacy: An increase in adult literacy by one percentage point raises per capita income by somewhat more than $17 \$$, or likewise a one standard deviation increase in adult literacy raises income by about $391 \$$.

It may be added that our estimate of the influence of corruption on income is likely to be conservative since our specification takes physical capital as exogenous. As shown by Mauro (1995) corruption has a strong adverse effect on capital formation. This effect is ignored in our estimate.

\section{b) The-Corruption-Pollution Relationship Reconsidered}

The analysis of section 3 disregarded the dependence of income on corruption as well as possible interdependencies between the various pollutants due to correlated errors. Now that preferred specifications of both the corruption-income-pollution relationship (equation (1)) and the corruption-income relationship (equation (2)) have been selected, we shall consider

\footnotetext{
${ }^{31}$ The probability of ADLIT being insignificant in REG 3 is 6.9 percent, which we consider to be sufficiently low to justify inclusion of this variable.

${ }^{32}$ The corruption level varies between -2.24 and +1.21 SD around its mean. A one SD difference therefore roughly corresponds to the difference between a country with average corruption and a highly corrupt country.
} 
the overall corruption-pollution relationship, taking the above interdependencies into account. More specifically, we will treat the preferred specifications of the equations (1) - for the six ambient pollution indicators - and of equation (2) as a simultaneous equation system. The system is recursive and includes no cross-equation restrictions on the coefficients. Therefore, it is appropriate to use Zellner's technique of seemingly unrelated regressions (SUR). ${ }^{33}$

The estimated equation system and the results of the SUR estimation are shown in Table A4 in the Appendix. To facilitate the comparison with the OLS results (REG 3 in Table A3 and REG 3 in Table 4), Table 5 shows the estimated coefficients for the corruption variable, the associated $t$-statistics, and the $R$-squared of the respective regressions under OLS and SUR.

It is noteworthy that the SUR coefficients are somewhat lower than their OLS counterparts. When using SUR, the impact on per capita income of a one SD increase in corruption drops from a $1167 \$$ loss to a loss by $1082 \$$. The maximum impact on pollution of a one SD increase in corruption drops from 0.45 to 0.40 SD (GMS_SS) while the minimum impact drops from 0.26 to $0.21 \mathrm{SD}$ (TSP).

The $t$-statistics are in four cases lower under SUR than under OLS. Four out of the seven coefficients on CORR are significant at least at the 5 percent level, the other three at levels between 8 and 11 percent.

Table 5: Comparison of OLS and SUR Estimation

\begin{tabular}{|l|c|c|c|c|}
\hline $\begin{array}{l}\text { Dependent } \\
\text { variable }\end{array}$ & $\begin{array}{c}\text { Estimation } \\
\text { method }\end{array}$ & $\begin{array}{c}\text { Coefficient on } \\
\text { CORR }\end{array}$ & $\begin{array}{c}\text { t-statistic of } \\
\text { CORR }\end{array}$ & R-squared \\
\hline GNPPC & OLS & -1166.77 & 2.09 & 0.931 \\
& SUR & -1082.25 & 2.59 & 0.931 \\
\hline SO2 & OLS & 0.353 & 2.54 & 0.277 \\
& SUR & 0.343 & 2.02 & 0.277 \\
\hline NO2 & OLS & 0.407 & 1.93 & 0.046 \\
& SUR & 0.357 & 1.76 & 0.045 \\
\hline TSP & OLS & 0.255 & 2.15 & 0.636 \\
& SUR & 0.209 & 1.64 & 0.636 \\
\hline GMS_DO & OLS & 0.428 & 2.55 & 0.564 \\
& SUR & 0.364 & 2.61 & 0.562 \\
\hline GMS_PH & OLS & 0.391 & 1.53 & 0.051 \\
& SUR & 0.308 & 1.61 & 0.048 \\
\hline GMS_SS & OLS & 0.448 & 3.92 & 0.723 \\
& SUR & 0.404 & 3.61 & 0.722 \\
\hline
\end{tabular}

\footnotetext{
${ }^{33}$ SUR takes account of heteroskedasticity and correlation of errors across equations. Estimation techniques more sophisticated than SUR are not required in the present case: For the model specified in equations (4) and (5) the matrix of coefficients of the endogenous variables is triangular, implying that its determinant is 1 . Thus the Jacobian term in the loglikelihood function for the system (4), (5) vanishes, and the loglikelihood function has the same form as the loglikelihood function for a set of linear seemingly unrelated regressions (Davidson and McKinnon 1993, 644-645).
} 
Given that the simultaneity bias in our previous estimates implied an overstatement of the impacts of corruption on both income and pollution, an interesting question relates to the possibility of biases in our assessment of the income-pollution relationship. The most convenient way to address this problem is in terms of the peaks of the income-pollution relationship. In comparison with the peaks based on OLS as reported in Table 3, we find that the decreasing relationship for $\mathrm{NO}_{2}$, TSP, dissolved oxygen demand, and suspended solids is confirmed by the SUR estimation. For $\mathrm{SO}_{2}$ the peak is slightly higher under SUR than under OLS (5728 \$ instead of $5586 \$$ ), whereas for phosphorus concentration it is somewhat lower (17406 \$ instead of 17942 \$). The basic conclusions on the income-pollution relationship from section 3 thus remain valid.

\section{c) The Impact of Corruption on Pollution}

We are now ready to examine the total effect of corruption on pollution, as well as its composition in terms of the direct effect (via reduced stringency of environmental laws and environmental law enforcement) and the indirect effect (based on corruption's impact on prosperity), see equation (3).

In Figure 4, the effect on pollution of a one SD increase in corruption is plotted against per capita income. The effects are also expressed in terms of standard deviation units. The shape of these curves is an immediate consequence of the shape of the income-pollution relationships. $^{34}$

\footnotetext{
${ }^{34}$ The indirect effects shown in Figure 4 are the slopes of the income-pollution relationships as shown in Figure 3 , multiplied by the negative coefficient which measures the impact of corruption on income. Consider, e.g., $\mathrm{SO} 2$, which according to Figure 3 rises in income at low income levels. Because corruption reduces income, it leads to lower SO2 through this channel as long as income is low. Consequently, the indirect effect shown in Figure 4 is negative at low income levels. At higher income levels, SO2 decreases with income but, since corruption reduces income, the indirect effect of corruption on $\mathrm{SO} 2$ is now slightly positive. Finally, when income is very high, $\mathrm{SO} 2$ slightly increases in income, and the indirect corruption effect becomes negative. The qualitative shape of the indirect effect is, of course, transferred to the total effect. The same way of reasoning applies to the other pollutants.
} 
Figure 4: Effect on Pollution of a one SD Increase in Corruption (effects measured in SD)
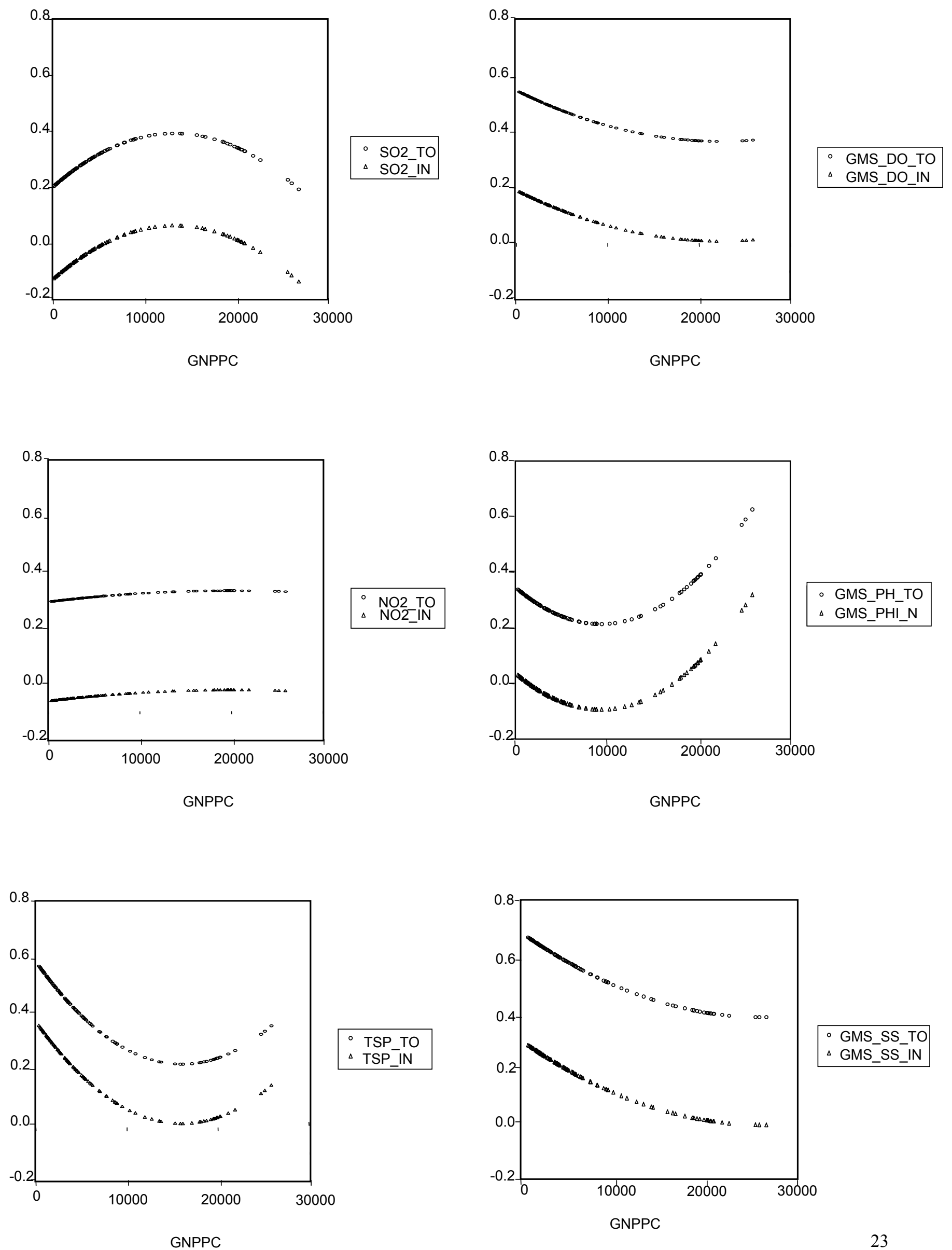
Consider first the indirect effect. Except for TSP and dissolved oxygen demand there exist income ranges at which the indirect effect of corruption on pollution is negative. That is, the reduction in income brought about by increased corruption may actually reduce pollution at some ranges of income. However, if present, this negative effect is rather small and dominated by the positive direct effect at all income levels.

An important result is that at low income levels there is a strong positive indirect effect of corruption on total suspended particles, dissolved oxygen demand, and suspended solids. This means that fighting corruption in low-income countries could substantially reduce these types of pollution, just by raising the income level.

With respect to the total effect of corruption on pollution, we find that it is positive for all pollutants considered and over the whole range of income. Similar to the indirect effect, the total effect on total suspended particles, dissolved oxygen demand, and suspended solids is strongest in poor countries. For phosphorus concentration in rivers, the effect is stronger in poor countries than in middle-income countries, though not stronger than in rich countries. ${ }^{35}$

A compact presentation of the magnitudes involved is given in Table 6, which shows the maximum and minimum effects of a one SD increase in corruption, differentiated by direct, indirect, and total effect.

Table 6: Maximum and Minimum Effects of a one SD Increase in Corruption

\begin{tabular}{|l|l|c|c|c|}
\hline & & Direct effect & Indirect effect & Total effect \\
\hline SO2 & Maximum & 0.343 & 0.071 & 0.414 \\
& Minimum & 0.343 & -0.137 & 0.206 \\
\hline NO2 & Maximum & 0.358 & -0.024 & 0.334 \\
& Minimum & 0.358 & -0.063 & 0.295 \\
\hline TSP & Maximum & 0.209 & 0.357 & 0.566 \\
& Minimum & 0.209 & 0.012 & 0.221 \\
\hline GMS_DO & Maximum & 0.364 & 0.185 & 0.549 \\
& Minimum & 0.364 & 0.005 & 0.369 \\
\hline GMS_PH & Maximum & 0.308 & 0.316 & 0.624 \\
& Minimum & 0.308 & -0.094 & 0.214 \\
\hline GMS_SS & Maximum & 0.404 & 0.257 & 0.661 \\
& Minimum & 0.404 & -0.041 & 0.363 \\
\hline
\end{tabular}

The maximum total effect of a one SD increase in corruption is between $0.3 \mathrm{SD}\left(\mathrm{NO}_{2}\right)$ and almost $0.7 \mathrm{SD}$ (suspended solids). The minimum total effect is between $0.2 \mathrm{SD}\left(\mathrm{SO}_{2}\right)$ and almost 0.4 (dissolved oxygen demand).

\footnotetext{
${ }^{35}$ It should, however, be recalled from our discussion of the income-pollution relationship that - because of the number of observations available - the confidence to be placed in the estimated relationships is lower at high income levels than at low and middle income levels.
} 
To make these results more vivid, note that a one SD reduction in corruption would take a high-corruption country close to the average corruption level. For a country suffering from the highest $\mathrm{NO}_{2}$ levels, this would imply that $\mathrm{NO}_{2}$ gets reduced from $3.8 \mathrm{SD}$ above average to about 3.5 above average. For a country with high phosphorus pollution, the corresponding reduction would be from 4.1 SD above average to 3.5 SD above average in the most favorable case ('maximum' in Table 6). In the most unfavorable case ('minimum' in Table 6) there would be a reduction to $3.9 \mathrm{SD}$ above average.

Even though our results represent purely statistical relationships, it may be useful to illustrate them by way of an example. Consider the case of Burundi, which is ranked as highly corrupt (1.2 SD above average), and Peru, whose corruption level is more moderate (0.2 above average). If the corruption level of Burundi were reduced down to the level prevailing in Peru, this would be associated with an increase of Burundi's per capita income from less than one fifth to somewhat more than one half the level of Peru. With respect to pollution such a reduced corruption level would be associated with a substantial decline in total suspended particles (from 1.65 to 1.1 SD above average), dissolved oxygen demand (from 1.4 to 0.85 $\mathrm{SD}$ ) and suspended solids (from 1.65 to $1.0 \mathrm{SD}$.)

This illustrates the probably most important conclusion to be drawn from our results, namely that reducing corruption is especially important for poor countries, not only for economic, but also for environmental reasons.

\section{d) Robustness}

The robustness of our results was checked with respect to the linear specification of the effect of corruption in equations (4) and (5). Reestimating a version of the system in which all equations are augmented by corruption-squared, to test for nonlinearity of the effects of corruption, yields insignificant estimates for corruption-squared in five out of the six pollution equations. Only for phosphorus concentration the squared term was found to be significant at a level below 5 percent. The squared term was also insignificant in the income equation. We conclude from these results that it is generally appropriate to take the direct effect of corruption on pollution as well as the effect on income to be linear.

\section{Conclusions}

This paper investigated the impact of corruption on pollution via two channels: (a) reduced stringency of environmental laws and their enforcement (direct effect), and (b) reduced levels of per capita income (indirect effect). Using six indicators of ambient air and water pollution, 
we found that pollution is monotonically increasing in corruption. In terms of the indirect effect which contributes to this overall result, corruption may reduce or enhance pollution, depending on the income level. However, even if corruption reduces pollution via its effect on income, this indirect effect is invariably dominated by the direct effect.

In quantitative terms, the maximum total effect of a one standard deviation increase in corruption is between 0.3 standard deviations in the case of nitrogen oxide concentration in urban air and almost 0.7 standard deviations in the case of suspended solids in river basins. The minimum total effect is between 0.2 standard deviations in the case of sulphur dioxide concentration in urban air and almost 0.4 standard deviations in the case of dissolved oxygen demand in rivers.

From a policy point of view, the most important result appears to be that, for most pollutants, the effect of corruption on pollution is particularly strong in low-income countries. Reducing corruption is therefore especially important for the less developed regions. By reducing corruption, low-income countries could considerably improve both their economic and environmental conditions. With rising income, a better environmental quality would become desirable and 'affordable'. At the same time, lower corruption would allow this demand for a better environment to become satisfied in terms of stricter environmental laws and stricter enforcement of these laws. Reducing corruption therefore seems to be of key importance for improving environmental quality especially in developing countries. 


\section{References}

Antweiler, W., Copeland, B.R., Taylor, M.S. (2001), Is Free Trade Good for the Environment?, American Economic Review 91, 877-908.

Barrett, S., Graddy, K. (2000), Freedom, Growth, and the Environment, Environment and Development Economics 5, 433-456.

Barro, R. (1991), Economic Growth in a Cross-Section of Countries, Quarterly Journal of Economics 106, 407-444.

Barro, R., Sala-i-Martin, X. (1995), Economic Growth, New York: McGraw Hill.

Damania, R., Fredriksson, P.G., List, J.A. (2000), Trade Liberalization, Corruption and Environmental Policy Formation: Theory and Evidence, CIES Discussion Paper 0047, University of Adelaide.

Davidson, R., McKinnon, J.G. (1993), Estimation and Inference in Econometrics, New York, Oxford: Oxford University Press.

Desai, U. (1998), ed., Ecological Policy and Politics in Developing Countries: Growth, Democracy and Environment, Albany: State University of New York Press.

Fredriksson, P.G., List, J.A., Millimet, D.L. (2002), Bureaucratic Corruption, Environmental Policy and Inbound US FDI: Theory and Evidence, forthcoming Journal of Public Economics.

Fredriksson, P.G., Svenson, J. (2002), Political Instability, Corruption and Policy Formation: The Case of Environmental Policy, forthcoming Journal of Public Economics.

Grossman, G.M., Krueger, A. B. (1995), Economic Growth and the Environment, Quarterly Journal of Economics 110, 353-377.

Hafner, O. (1998), The Role of Corruption in the Misappropriation of Tropical Forest Resources and in Tropical Forest Destruction, Transparency International Working Paper, www.transparency.org/documents/work-papers.

Hall, R., Jones, C. (1999), Why do Some Countries Produce so much more Output per Worker than Others?, Quarterly Journal of Economics 114, 83-116.

Hilton, F.G.H., Levinson, A. (1998), Factoring the Environmental Kuznets Curve: Evidence from Automotive Lead Emissions, Journal of Environmental Economics and Management 35, 126-141.

Holtz-Eakin, D., Selden, T.M. (1995), Stoking the Fires? $\mathrm{CO}_{2}$ Emissions and Economic Growth, Journal of Public Economics 57, 85-101.

Kaufmann, D., Kraay, A., Zoido-Lobaton, P. (1999), Governance Matters, World Bank Policy Research Working Paper, Washington D.C.: The World Bank.

Kaufmann, D., Kraay, A., Zoido-Lobaton, P. (2000), Aggregating Governance Indicators, World Bank Policy Research Working Paper, Washington D.C.: The World Bank.

Lambsdorff, J.G. (1999), Corruption in Empirical Research - A Review, Transparency International Working Paper, www.transparency.org/documents/work-papers. 
Lippe, M. (1999), Corruption and Environment at the Local Level, Transparency International Working Paper, www.transparency.org/documents/work-papers.

Lopez, R., Mitra, S. (2000) Corruption, Pollution, and the Kuznets Environment Curve, Journal of Environmental Economics and Management 40, 137-150.

Mauro, P. (1995), Corruption and Growth, Quarterly Journal of Economics 110, 681-712

OECD (1991), The State of the Environment, Paris: Organization for Economic Cooperation and Development.

Rose-Ackerman, S. (1975), The Economics of Corruption, Journal of Public Economics 4, 187-203.

Selden, T.M., Song, D. (1994), Environmental Quality and Development: Is there a Kuznets Curve for Air Pollution Emissions?, Journal of Environmental Economics and Management $27,147-162$.

Schmalensee, R., Stoker, T.M., Judson, R.A. (1998), World Carbon Dioxide Emissions: 19502050, Review of Economics and Statistics 80, 15-27.

Shafik, N. (1994), Economic Development and Environmental Quality, Oxford Economic Papers 46, 757-773.

Transparency International (2000), TI Source Book 2000, www.transparency.org/sourcebook.

WEF/YCELP/CIESIN (2001), 2001 Environmental Sustainability Index, World Economic Forum (WEF), Yale Center for Environmental Law and Policy (YCELP), Center for International Earth Science Information Network (CIESIN), January 2001, www.ciesin.columbia.edu/indicators/ESI 


\section{Appendix}

Table A1: Summary Statistics

$\begin{array}{lcccccc} & \text { ADLIT } & \text { BODWAT } & \text { CAPPC } & \text { CORR } & \text { FERTHA } & \text { GMS_DO } \\ \text { Mean } & 75.87097 & 0.000 & 27902.25 & 0.000 & 0.000 & 0.000 \\ \text { Median } & 83.00000 & 0.020 & 18033.74 & 0.330 & 0.225 & 0.235 \\ \text { Maximum } & 98.00000 & 4.250 & 109097.8 & 1.210 & 1.640 & 1.920 \\ \text { Minimum } & 14.00000 & -0.900 & 330.2996 & -2.240 & -2.760 & -2.330 \\ \text { Std. Dev. } & 22.85409 & 1.000 & 29441.49 & 1.000 & 1.000 & 1.000 \\ \text { Observations } & 93 & 122 & 95 & 122 & 122 & 122 \\ & & & & & & \\ & & & & & & \\ \text { Mean } & \text { GMS_PH } & \text { GMS_SS } & \text { GNPPC } & \text { NO2 } & \text { NOXKM } & \text { OPEC } \\ \text { Median } & -0.000 & -0.000 & 7167.736 & 0.000 & 0.000 & 0.081 \\ \text { Maximum } & 0.070 & 0.195 & 4145.000 & 0.095 & -0.120 & 0.000 \\ \text { Minimum } & 4.120 & 1.770 & 25880.00 & 3.810 & 2.250 & 1.000 \\ \text { Std. Dev. } & -1.110 & -2.480 & 330.0000 & -2.810 & -1.960 & 0.000 \\ \text { Observations } & 1.000 & 1.000 & 7043.588 & 1.000 & 1.000 & 0.275 \\ & 122 & 122 & 106 & 122 & 122 & 122 \\ & & & & & & \\ & & & & & & \\ \text { Mean } & \text { PESTHA } & \text { RDPERS } & \text { SO2 } & \text { SO2KM } & \text { TSP } & \text { VOCKM } \\ \text { Median } & 0.000 & 0.000 & 0.000 & 0.000 & 0.000 & 0.000 \\ \text { Maximum } & -0.355 & -0.455 & 0.130 & -0.340 & 0.125 & -0.040 \\ \text { Minimum } & 4.060 & 2.640 & 3.520 & 4.940 & 1.770 & 2.220 \\ \text { Std. Dev. } & -0.700 & -1.530 & -1.520 & -0.520 & -1.740 & -1.680 \\ \text { Observations } & 1.000 & 1.000 & 1.000 & 1.000 & 1.000 & 1.000 \\ & 122 & 122 & 122 & 122 & 122 & 122\end{array}$


Table A2: Correlation Matrix

\begin{tabular}{|l|c|c|c|c|c|c|}
\hline & ADLIT & BODWAT & CAPPC & CORR & FERTHA & GMS_DO \\
\hline ADLIT & 1.000 & 0.045 & 0.664 & -0.615 & 0.602 & -0.619 \\
\hline BODWAT & 0.045 & 1.000 & 0.030 & -0.063 & 0.132 & 0.018 \\
\hline CAPPC & 0.664 & 0.030 & 1.000 & -0.867 & 0.514 & -0.739 \\
\hline CORR & -0.615 & -0.063 & -0.867 & 1.000 & -0.561 & 0.757 \\
\hline FERTHA & 0.602 & 0.132 & 0.514 & -0.561 & 1.000 & -0.507 \\
\hline GMS_DO & -0.619 & 0.018 & -0.739 & 0.757 & -0.507 & 1.000 \\
\hline GMS_PH & 0.002 & 0.929 & -0.081 & 0.059 & 0.078 & 0.164 \\
\hline GMS_SS & -0.686 & -0.120 & -0.790 & 0.821 & -0.615 & 0.833 \\
\hline GNPPC & 0.676 & 0.136 & 0.950 & -0.884 & 0.585 & -0.741 \\
\hline NO2 & -0.038 & 0.036 & -0.085 & 0.170 & -0.019 & -0.010 \\
\hline NOXKM & 0.407 & 0.283 & 0.596 & -0.581 & 0.362 & -0.443 \\
\hline OPEC & -0.002 & -0.124 & -0.039 & 0.240 & -0.009 & 0.185 \\
\hline PESTHA & 0.436 & 0.236 & 0.367 & -0.388 & 0.547 & -0.368 \\
\hline RDPERS & 0.622 & 0.155 & 0.883 & -0.835 & 0.511 & -0.759 \\
\hline SO2 & -0.375 & -0.000 & -0.589 & 0.582 & -0.282 & 0.409 \\
\hline SO2KM & 0.325 & 0.346 & 0.379 & -0.377 & 0.365 & -0.307 \\
\hline TSP & -0.673 & -0.046 & -0.790 & 0.764 & -0.566 & 0.754 \\
\hline VOCKM & 0.161 & 0.255 & 0.272 & -0.231 & 0.219 & -0.126 \\
\hline
\end{tabular}

\begin{tabular}{|l|l|l|l|l|l|l|}
\hline & GMS_PH & GMS_SS & GNPPC & NO2 & NOXKM & OPEC \\
\hline ADLIT & 0.002 & -0.686 & 0.676 & -0.038 & 0.407 & -0.002 \\
\hline BODWAT & 0.929 & -0.120 & 0.136 & 0.036 & 0.283 & -0.124 \\
\hline CAPPC & -0.081 & -0.790 & 0.950 & -0.085 & 0.596 & -0.039 \\
\hline CORR & 0.059 & 0.821 & -0.884 & 0.170 & -0.581 & 0.240 \\
\hline FERTHA & 0.078 & -0.615 & 0.585 & -0.019 & 0.362 & -0.009 \\
\hline GMS_DO & 0.164 & 0.833 & -0.741 & -0.010 & -0.443 & 0.185 \\
\hline GMS_PH & 1.000 & 0.004 & 0.004 & 0.048 & 0.215 & 0.011 \\
\hline GMS_SS & 0.004 & 1.000 & -0.806 & 0.120 & -0.574 & 0.142 \\
\hline GNPPC & 0.004 & -0.806 & 1.000 & -0.057 & 0.657 & -0.085 \\
\hline NO2 & 0.048 & 0.120 & -0.057 & 1.000 & -0.003 & 0.061 \\
\hline NOXKM & 0.215 & -0.574 & 0.657 & -0.003 & 1.000 & -0.126 \\
\hline OPEC & 0.011 & 0.142 & -0.085 & 0.061 & -0.126 & 1.000 \\
\hline PESTHA & 0.172 & -0.420 & 0.484 & 0.166 & 0.433 & -0.112 \\
\hline RDPERS & 0.020 & -0.801 & 0.904 & -0.110 & 0.671 & -0.120 \\
\hline SO2 & 0.045 & 0.506 & -0.571 & 0.220 & -0.303 & -0.010 \\
\hline SO2KM & 0.341 & -0.445 & 0.440 & 0.058 & 0.630 & -0.100 \\
\hline TSP & 0.099 & 0.842 & -0.796 & 0.211 & -0.482 & 0.061 \\
\hline VOCKM & 0.242 & -0.260 & 0.348 & 0.043 & 0.861 & 0.092 \\
\hline
\end{tabular}




\begin{tabular}{|l|l|l|l|l|l|l|}
\hline & PESTHA & RDPERS & SO2 & SO2KM & TSP & VOCKM \\
\hline ADLIT & 0.436 & 0.622 & -0.375 & 0.325 & -0.673 & 0.161 \\
\hline BODWAT & 0.236 & 0.155 & -0.000 & 0.346 & -0.046 & 0.255 \\
\hline CAPPC & 0.367 & 0.883 & -0.589 & 0.379 & -0.790 & 0.272 \\
\hline CORR & -0.388 & -0.835 & 0.582 & -0.377 & 0.764 & -0.231 \\
\hline FERTHA & 0.547 & 0.511 & -0.282 & 0.365 & -0.566 & 0.219 \\
\hline GMS_DO & -0.368 & -0.759 & 0.409 & -0.307 & 0.754 & -0.126 \\
\hline GMS_PH & 0.172 & 0.020 & 0.045 & 0.341 & 0.099 & 0.242 \\
\hline GMS_SS & -0.420 & -0.801 & 0.506 & -0.445 & 0.842 & -0.260 \\
\hline GNPPC & 0.484 & 0.904 & -0.571 & 0.440 & -0.796 & 0.348 \\
\hline NO2 & 0.166 & -0.110 & 0.220 & 0.058 & 0.211 & 0.043 \\
\hline NOXKM & 0.433 & 0.671 & -0.303 & 0.630 & -0.482 & 0.861 \\
\hline OPEC & -0.112 & -0.120 & -0.010 & -0.100 & 0.061 & 0.092 \\
\hline PESTHA & 1.000 & 0.378 & -0.147 & 0.452 & -0.340 & 0.336 \\
\hline RDPERS & 0.378 & 1.000 & -0.521 & 0.413 & -0.744 & 0.353 \\
\hline SO2 & -0.147 & -0.521 & 1.000 & -0.165 & 0.504 & -0.161 \\
\hline SO2KM & 0.452 & 0.413 & -0.165 & 1.000 & -0.340 & 0.510 \\
\hline TSP & -0.340 & -0.744 & 0.504 & -0.340 & 1.000 & -0.187 \\
\hline VOCKM & 0.336 & 0.353 & -0.161 & 0.510 & -0.187 & 1.000 \\
\hline
\end{tabular}


Table A3: Regression Results

\begin{tabular}{|c|c|c|c|c|}
\hline SO2 & Reg1 & Reg2 & Reg3 & $\operatorname{Reg} 4$ \\
\hline \multirow[t]{2}{*}{ CONST } & 0,1959907 & 0,1930068 & $-0,1073133$ & $-0,1968918$ \\
\hline & $(-1,2949339)$ & $(-1,2552259)$ & $(-0.4744701)$ & $(-0.764094)$ \\
\hline \multirow[t]{2}{*}{ GNP } & 9,81E-05 & 0,0001033 & 0,0001315 & 0,0001619 \\
\hline & $(-1,0969902)$ & $(-1,0959688))$ & $(-1,3996516)$ & $(1.5303421)$ \\
\hline \multirow[t]{2}{*}{ GNP2 } & $-1,84 \mathrm{E}-08$ & $-1,90 \mathrm{E}-08$ & $-1,50 \mathrm{E}-08$ & $-1,66 \mathrm{E}-08$ \\
\hline & $(-2,1740594)$ & $(-2,1021677)$ & $(-1,9154804)$ & $(-1,9702027)$ \\
\hline \multirow[t]{2}{*}{ GNP3 } & $5,24 \mathrm{E}-13$ & $5,41 \mathrm{E}-13$ & $3,87 \mathrm{E}-13$ & $4,22 \mathrm{E}-13$ \\
\hline & $(2,4655982)$ & $(2,3562786)$ & $(2,0255829)$ & $(2,0556039)$ \\
\hline \multirow[t]{2}{*}{ OPEC } & & $-0,1161561$ & & $-0,4811255$ \\
\hline & & $(-0,461357)$ & & $(-1,6044446)$ \\
\hline \multirow[t]{2}{*}{ CORR } & & & 0,3532654 & 0,4432046 \\
\hline & & & $(2,5449412)$ & $(2,642717)$ \\
\hline $\mathrm{R} 2$ & 0,2470019 & 0,2477283 & 0,2765965 & 0,2871396 \\
\hline R2A & 0,2248549 & 0,2179353 & 0,2479469 & 0,2514966 \\
\hline$p$-value & $<0.0001$ & $<0.0001$ & $<0.0001$ & $<0.0001$ \\
\hline
\end{tabular}

\begin{tabular}{|l|r|r|r|r|}
\hline NO2 & Reg1 & Reg2 & Reg3 & Reg4 \\
\hline CONST & 0,0377756 & 0,0412451 & $-0,3112599$ & $-0,3552071$ \\
\hline & $(0,216975)$ & $(0,2331596)$ & $(-1,2536828)$ & $(-1,20237)$ \\
\hline GNP & $3,65 \mathrm{E}-05$ & $3,04 \mathrm{E}-05$ & $7,50 \mathrm{E}-05$ & $8,99 \mathrm{E}-05$ \\
\hline & $(0,3044001)$ & $(0,2414242)$ & $(0,6134514)$ & $(0,6651726)$ \\
\hline GNP2 & $-6,49 \mathrm{E}-09$ & $-5,81 \mathrm{E}-09$ & $-2,60 \mathrm{E}-09$ & $-3,37 \mathrm{E}-09$ \\
\hline & $(-0,5249173)$ & $(-0,4484647)$ & $(-0,2120103)$ & $(-0,2682833)$ \\
\hline GNP3 & $2,08 \mathrm{E}-13$ & $1,89 \mathrm{E}-13$ & $5,14 \mathrm{E}-14$ & $6,86 \mathrm{E}-14$ \\
\hline & $(0,6347712)$ & $(0,548565)$ & $(0,1552623)$ & $(0,206285)$ \\
\hline OPEC & & 0,1350637 & & $-0,2360403$ \\
\hline & & $(0,809179)$ & & $(-0,750394)$ \\
\hline CORR & & & 0,4065301 & 0,4506542 \\
\hline R2 & & & $(1,9345448)$ & $(1,747928)$ \\
\hline R2A & 0,0100492 & 0,0109472 & 0,0458885 & 0,0482091 \\
\hline p-value & $-0,019067$ & $-0,0282232$ & 0,008102 & 0,0006195 \\
\hline
\end{tabular}

\begin{tabular}{|c|c|c|c|c|}
\hline TSP & Reg1 & Reg2 & Reg3 & Reg4 \\
\hline \multirow[t]{2}{*}{ CONST } & 1,2927813 & 1,3027934 & 1,0737558 & 1,1132971 \\
\hline & $(7,7548999)$ & $(7,7887953)$ & $(4,9008074)$ & $(4,8909263)$ \\
\hline \multirow[t]{2}{*}{ GNP } & $-3,53 E-04$ & $-0,0003705$ & $-0,0003286$ & $-0,000342$ \\
\hline & $(-4,6217197)$ & $(-4,8302601)$ & $(-4,0541429)$ & $(-4,0225087)$ \\
\hline \multirow[t]{2}{*}{ GNP2 } & $1,76 \mathrm{E}-08$ & $1,95 \mathrm{E}-08$ & $2,00 \mathrm{E}-08$ & $2,07 \mathrm{E}-08$ \\
\hline & $(2,5507478)$ & $(2,8663171)$ & $(3,1733596)$ & $(3,1995543)$ \\
\hline \multirow[t]{2}{*}{ GNP3 } & $-3,13 E-13$ & $-3,69 \mathrm{E}-13$ & $-4,11 \mathrm{E}-13$ & $-4,27 \mathrm{E}-13$ \\
\hline & $(-1,8086545)$ & $(-2,2243881)$ & $(-2,7291409)$ & $(-2,7988049)$ \\
\hline \multirow[t]{2}{*}{ OPEC } & & 0,3897563 & & 0,212376 \\
\hline & & $(1,2680017)$ & & $(0,6305176)$ \\
\hline \multirow[t]{2}{*}{ CORR } & & & 0,2551043 & 0,2154038 \\
\hline & & & $(2,1477051)$ & $(1,6729038)$ \\
\hline $\mathrm{R} 2$ & 0,6226984 & 0,6299336 & 0,6363524 & 0,6381699 \\
\hline $\mathrm{R} 2 \mathrm{~A}$ & 0,6116013 & 0,6152775 & 0,6219505 & 0,6200784 \\
\hline$p$-value & $<0.0001$ & $<0.0001$ & $<0.0001$ & $<0.0001$ \\
\hline
\end{tabular}




\begin{tabular}{|c|c|c|c|c|}
\hline GMS_DO & Reg1 & Reg2 & Reg3 & Reg4 \\
\hline \multirow[t]{2}{*}{ CONST } & 0,9967249 & 1,0153314 & 0,6290706 & 0,7108669 \\
\hline & $(5,7845084)$ & $(5,8195822)$ & $(2,733394)$ & $(2,7570866)$ \\
\hline \multirow[t]{2}{*}{ GNP } & $-0,000196$ & $-0,000229$ & $-0,0001555$ & $-0,0001833$ \\
\hline & $(-2,104012)$ & $(-2,4049015)$ & $(-1,7172185)$ & $(-1,8851826)$ \\
\hline \multirow[t]{2}{*}{ GNP2 } & $2,58 \mathrm{E}-09$ & 6,23E-09 & 6,67E-09 & 8,10E-09 \\
\hline & $(0,2999865)$ & $(0,7130675)$ & $(0,8034238)$ & $(0,9537323)$ \\
\hline \multirow[t]{2}{*}{ GNP3 } & $7,78 \mathrm{E}-14$ & $-2,72 \mathrm{E}-14$ & $-8,75 \mathrm{E}-14$ & $-1,20 \mathrm{E}-13$ \\
\hline & $(0,3694385)$ & $(-0,1286479)$ & $(-0,4195604)$ & $(-0,5649547)$ \\
\hline \multirow[t]{2}{*}{ OPEC } & & 0,7243247 & & 0,4393269 \\
\hline & & $(3,1390009)$ & & $(1,4662598)$ \\
\hline \multirow[t]{2}{*}{ CORR } & & & 0,4282158 & 0,3460902 \\
\hline & & & $(2,5480332)$ & $(1,736435)$ \\
\hline $\mathrm{R} 2$ & 0,5248604 & 0,5498736 & 0,5633719 & 0,5711573 \\
\hline $\mathrm{R} 2 \mathrm{~A}$ & 0,5108857 & 0,5320468 & 0,5460797 & 0,5497152 \\
\hline$p$-value & $<0.0001$ & $<0.0001$ & $<0.0001$ & $<0.0001$ \\
\hline
\end{tabular}

\begin{tabular}{|c|c|c|c|c|}
\hline GMS_PH & Reg1 & Reg2 & Reg3 & Reg4 \\
\hline \multirow[t]{2}{*}{ CONST } & $-0,0041548$ & 0,0001129 & $-0,3401403$ & $-0,3744959$ \\
\hline & $(-0,030571)$ & $(0,0008259)$ & $(-1,3941068)$ & $(-1,3665881)$ \\
\hline \multirow[t]{2}{*}{ GNP } & $-4,70 \mathrm{E}-05$ & $-5,46 \mathrm{E}-05$ & $-9,99 \mathrm{E}-06$ & 1,67E-06 \\
\hline & $(-0,5384869)$ & $(-0,6198572)$ & $(-0,1175433)$ & $(0,0195272)$ \\
\hline \multirow[t]{2}{*}{ GNP2 } & $8,12 \mathrm{E}-09$ & 8,96E-09 & 1,19E-08 & $1,13 \mathrm{E}-08$ \\
\hline & $(0,8198223)$ & $(0,9039185)$ & $(1,0823973)$ & $(1,0644059)$ \\
\hline \multirow[t]{2}{*}{ GNP3 } & $-2,79 \mathrm{E}-13$ & $-3,04 \mathrm{E}-13$ & $-4,31 \mathrm{E}-13$ & $-4,17 \mathrm{E}-13$ \\
\hline & $(-0,995811)$ & $(-1,0850295)$ & $(-1,3240175)$ & $(-1,3205576)$ \\
\hline \multirow[t]{2}{*}{ OPEC } & & 0,1661336 & & $-0,1845236$ \\
\hline & & $(0,4168421)$ & & $(-0,3653791)$ \\
\hline \multirow[t]{2}{*}{ CORR } & & & 0,3913305 & 0,4258244 \\
\hline & & & $(1,5319206)$ & $(1,4583678)$ \\
\hline R2 & 0,0138828 & 0,0154042 & 0,051069 & 0,0526569 \\
\hline R2A & $-0,0151206$ & $-0,0235896$ & 0,0134875 & 0,0052898 \\
\hline$p$-value & 0.70 & 0.81 & 0.25 & 0.36 \\
\hline
\end{tabular}

\begin{tabular}{|c|c|c|c|c|}
\hline GMS_SS & Reg1 & Reg2 & Reg3 & Reg4 \\
\hline \multirow[t]{2}{*}{ CONST } & 1,2000993 & 1,2147464 & 0,815478 & 0,8597738 \\
\hline & $(7,725645)$ & $(7,8511954)$ & $(4,2034517)$ & $(4,1873149)$ \\
\hline \multirow[t]{2}{*}{ GNP } & $-2,74 \mathrm{E}-04$ & $-0,0002994$ & $-0,0002311$ & $-0,0002461$ \\
\hline & $(-3,8222959)$ & $(-4,1852891)$ & $(-3,3158475)$ & $(-3,3220338)$ \\
\hline \multirow[t]{2}{*}{ GNP2 } & $6,19 \mathrm{E}-09$ & 9,07E-09 & 1,05E-08 & $1,13 \mathrm{E}-08$ \\
\hline & $(0,9658583)$ & $(1,4087537)$ & $(1,7195125)$ & $(1,7929961)$ \\
\hline \multirow[t]{2}{*}{ GNP3 } & $4,67 \mathrm{E}-14$ & $-3,60 \mathrm{E}-14$ & $-1,26 \mathrm{E}-13$ & $-1,44 \mathrm{E}-13$ \\
\hline & $(0,2825769)$ & $(-0,2184857)$ & $(-0,7766973)$ & $(-0,8665641)$ \\
\hline \multirow[t]{2}{*}{ OPEC } & & 0,5701888 & & 0,2379124 \\
\hline & & $(3,293833)$ & & $(1,5041457)$ \\
\hline \multirow[t]{2}{*}{ CORR } & & & 0,4479777 & 0,4035036 \\
\hline & & & $(3,9222279)$ & $(3,1929638)$ \\
\hline $\mathrm{R} 2$ & 0,6813303 & 0,6965716 & 0,7227741 & 0,7250191 \\
\hline $\mathrm{R} 2 \mathrm{~A}$ & 0,6719577 & 0,6845546 & 0,7117949 & 0,7112701 \\
\hline $\mathrm{p}$-value & $<0.0001$ & $<0.0001$ & $<0.0001$ & $<0.0001$ \\
\hline
\end{tabular}




\begin{tabular}{|l|r|r|r|r|}
\hline NOXKM & Reg1 & Reg2 & Reg3 & Reg4 \\
\hline CONST & $-0,5744888$ & $-0,5838907$ & $-0,5513028$ & $-0,6269513$ \\
\hline & $(-2,5657497)$ & $(-2,6022307)$ & $(-2,0783455)$ & $(-2,3008571)$ \\
\hline GNP & $5,84 \mathrm{E}-05$ & $7,50 \mathrm{E}-05$ & $5,58 \mathrm{E}-05$ & $8,15 \mathrm{E}-05$ \\
\hline & $(0,6059946)$ & $(0,7656305)$ & $(0,576725)$ & $(0,8176475)$ \\
\hline GNP2 & $3,74 \mathrm{E}-09$ & $1,90 \mathrm{E}-09$ & $3,48 \mathrm{E}-09$ & $2,16 \mathrm{E}-09$ \\
\hline & $(0,4300588)$ & $(0,2107888)$ & $(0,3845807)$ & $(0,2352369)$ \\
\hline GNP3 & $-1,18 \mathrm{E}-13$ & $-6,52 \mathrm{E}-14$ & $-1,08 \mathrm{E}-13$ & $-7,82 \mathrm{E}-14$ \\
\hline & $(-0,5462546)$ & $(-0,2858841)$ & $(-0,4606401)$ & $(-0,328106)$ \\
\hline OPEC & & $-0,3659997$ & & $-0,4063072$ \\
\hline & & $(-1,7224636)$ & & $(-1,553522)$ \\
\hline CORR & & & $-0,0270053$ & 0,0489477 \\
\hline & & & $(-0,1445295)$ & $(0,2387864)$ \\
\hline R2 & & & 0,3689134 & 0,3761255 \\
\hline R2A & 0,3687475 & 0,3756644 & 0,3439198 & 0,3449317 \\
\hline p-value & 0,3501812 & 0,3509382 & $<0.0001$ & $<0.0001$ \\
\hline
\end{tabular}

\begin{tabular}{|l|r|r|r|r|}
\hline SO2KM & Reg1 & Reg2 & Reg3 & Reg4 \\
\hline CONST & $-0,4856053$ & $-0,4968131$ & $-0,5830336$ & $-0,6996104$ \\
\hline & $(-2,8901697)$ & $(-2,9357239)$ & $(-2,0950458)$ & $(-2,2086789)$ \\
\hline GNP & $6,01 \mathrm{E}-05$ & $7,99 \mathrm{E}-05$ & $7,08 \mathrm{E}-05$ & 0,0001104 \\
\hline & $(0,5630096)$ & $(0,7321291)$ & $(0,6394898)$ & $(0,9298423)$ \\
\hline GNP2 & $5,36 \mathrm{E}-09$ & $3,16 \mathrm{E}-09$ & $6,45 \mathrm{E}-09$ & $4,41 \mathrm{E}-09$ \\
\hline & $(0,4949317)$ & $(0,2860612)$ & $(0,5745813)$ & $(0,3933951)$ \\
\hline GNP3 & $-2,72 \mathrm{E}-13$ & $-2,09 \mathrm{E}-13$ & $-3,16 \mathrm{E}-13$ & $-2,71 \mathrm{E}-13$ \\
\hline & $(-0,9760915)$ & $(-0,7341072)$ & $(-1,055576)$ & $(-0,9131172)$ \\
\hline OPEC & & $-0,436302$ & & $-0,626133$ \\
\hline CORR & & $(-2,8096456)$ & & $(-1,899402)$ \\
\hline & & & 0,1134772 & 0,2305233 \\
\hline R2 & & & $(0,4518432)$ & $(0,7861926)$ \\
\hline R2A & 0,1590992 & 0,1683038 & 0,1618421 & 0,1778807 \\
\hline p-value & 0,1343668 & 0,1353654 & 0,1286477 & 0,1367748 \\
\hline
\end{tabular}

\begin{tabular}{|c|c|c|c|c|}
\hline VOCKM & $\operatorname{Reg} 1$ & Reg2 & Reg3 & Reg4 \\
\hline \multirow[t]{2}{*}{ CONST } & $-0,2088442$ & $-0,1897272$ & $-0,4833715$ & $-0,3775466$ \\
\hline & $(-0,748526)$ & $(-0,6834037)$ & $(-1,5346272)$ & $(-1,1404336)$ \\
\hline \multirow[t]{2}{*}{ GNP } & $-4,61 \mathrm{E}-05$ & $-8,00 \mathrm{E}-05$ & $-1,59 \mathrm{E}-05$ & $-5,18 \mathrm{E}-05$ \\
\hline & $(-0,3949736)$ & $(-0,6856801)$ & $(-0,1375579)$ & $(-0,4368491)$ \\
\hline \multirow[t]{2}{*}{ GNP2 } & 9,02E-09 & $1,28 \mathrm{E}-08$ & 1,21E-08 & 1,39E-08 \\
\hline & $(0,8011963)$ & $(1,1614216)$ & $(1,0755798)$ & $(1,2528296)$ \\
\hline \multirow[t]{2}{*}{ GNP3 } & $-2,06 \mathrm{E}-13$ & $-3,14 \mathrm{E}-13$ & $-3,29 \mathrm{E}-13$ & $-3,71 \mathrm{E}-13$ \\
\hline & $(-0,6724338)$ & $(-1,0869475)$ & $(-1,0836545)$ & $(-1,2565433)$ \\
\hline \multirow[t]{2}{*}{ OPEC } & & 0,7441951 & & 0,5683844 \\
\hline & & $(5,0739885)$ & & $(2,5688748)$ \\
\hline \multirow[t]{2}{*}{ CORR } & & & 0,3197486 & 0,2134976 \\
\hline & & & $(1,6469945)$ & $(0,9606118)$ \\
\hline $\mathrm{R} 2$ & 0,1753956 & 0,204095 & 0,1987344 & 0,2128985 \\
\hline $\mathrm{R} 2 \mathrm{~A}$ & 0,1511425 & 0,1725741 & 0,1670011 & 0,1735434 \\
\hline$p$-value & $<0.0001$ & $<0.0001$ & $<0.0001$ & $<0.0001$ \\
\hline
\end{tabular}




\begin{tabular}{|l|r|r|r|r|}
\hline FERTHA & Reg1 & Reg2 & Reg3 & Reg4 \\
\hline CONST & $-1,3337268$ & $-1,3357853$ & $-1,2186598$ & $-1,2120071$ \\
\hline & $(-6,3575618)$ & $(-6,3504668)$ & $(-5,4766131)$ & $(-5,2403418)$ \\
\hline GNP & 0,0004329 & 0,0004365 & 0,0004202 & 0,000418 \\
\hline & $(5,75 \mathrm{E}+00)$ & $(5,6990312)$ & $(5,6408563)$ & $(5,4081508)$ \\
\hline GNP2 & $-2,67 \mathrm{E}-08$ & $-2,71 \mathrm{E}-08$ & $-2,79 \mathrm{E}-08$ & $-2,78 \mathrm{E}-08$ \\
\hline & $(-3,93 \mathrm{E}+00)$ & $(-3,8730201)$ & $(-4,0067137)$ & $(-3,9493196)$ \\
\hline GNP3 & $5,18 \mathrm{E}-13$ & $5,30 \mathrm{E}-13$ & $5,70 \mathrm{E}-13$ & $5,67 \mathrm{E}-13$ \\
\hline & $(3,00 \mathrm{E}+00)$ & $(2,9419008)$ & $(3,0985618)$ & $(3,0625493)$ \\
\hline OPEC & & $-0,0801325$ & & 0,0357316 \\
\hline & & $(-0,3959987)$ & & $(0,148736)$ \\
\hline CORR & & & $-0,1340214$ & $-0,1407009$ \\
\hline & & & $(-1,1058992)$ & $(-0,9913592)$ \\
\hline R2 & 0,5150283 & 0,5153758 & 0,51931 & 0,5193684 \\
\hline R2A & 0,5007645 & 0,4961828 & 0,5002727 & 0,4953368 \\
\hline p-value & $<0.0001$ & $<0.0001$ & $<0.0001$ & $<0.0001$ \\
\hline
\end{tabular}

\begin{tabular}{|c|c|c|c|c|}
\hline PESTHA & Reg1 & Reg2 & Reg3 & Reg4 \\
\hline \multirow[t]{2}{*}{ CONST } & $-0,5740387$ & $-0,5817842$ & $-0,7380751$ & $-0,83905$ \\
\hline & $(-4,4834488)$ & $(-4,5096021)$ & $(-3,4802035)$ & $(-3,67787)$ \\
\hline \multirow[t]{2}{*}{ GNP } & 4,78E-05 & $6,15 \mathrm{E}-05$ & 6,59E-05 & 0,0001001 \\
\hline & $(0,5832162)$ & $(0,7355246)$ & $(0,7703302)$ & $(1,1166535)$ \\
\hline \multirow[t]{2}{*}{ GNP2 } & 7,81E-09 & 6,29E-09 & $9,63 E-09$ & 7,87E-09 \\
\hline & $(8,05 E-01)$ & $(0,6350328)$ & $(0,9931629)$ & $(0,8015732)$ \\
\hline \multirow[t]{2}{*}{ GNP3 } & $-3,19 \mathrm{E}-13$ & $-2,76 \mathrm{E}-13$ & $-3,93 E-13$ & $-3,54 \mathrm{E}-13$ \\
\hline & $(-1,17 E+00)$ & $(-0,9815239)$ & $(-1,4117755)$ & $(-1,2559457)$ \\
\hline \multirow[t]{2}{*}{ OPEC } & & $-0,3015185$ & & $-0,5423353$ \\
\hline & & $(-2,4553671)$ & & $(-2,4806721)$ \\
\hline \multirow[t]{2}{*}{ CORR } & & & 0,1910571 & 0,2924386 \\
\hline & & & $(1,0555209)$ & $(1,4551757)$ \\
\hline R2 & 0,2989715 & 0,3038974 & 0,307684 & 0,3211673 \\
\hline $\mathrm{R} 2 \mathrm{~A}$ & 0,278353 & 0,276329 & 0,2802656 & 0,2872257 \\
\hline$p$-value & $<0.0001$ & $<0.0001$ & $<0.0001$ & $<0.0001$ \\
\hline
\end{tabular}

\begin{tabular}{|c|c|c|c|c|}
\hline BODWAT & $\operatorname{Reg} 1$ & Reg2 & Reg3 & Reg4 \\
\hline \multirow[t]{2}{*}{ CONST } & $-0,1024486$ & $-0,1115878$ & $-0,4033662$ & $-0,5451719$ \\
\hline & $(-0,7849175)$ & $(-0,8357701)$ & $(-1,6664256)$ & $(-1,9988574)$ \\
\hline \multirow[t]{2}{*}{ GNP } & $-4,32 \mathrm{E}-05$ & $-2,70 \mathrm{E}-05$ & $-1,00 \mathrm{E}-05$ & $3,81 \mathrm{E}-05$ \\
\hline & $(-5,09 \mathrm{E}-01)$ & $(-0,3082138)$ & $(-0,1203417)$ & $(0,4324391)$ \\
\hline \multirow[t]{2}{*}{ GNP2 } & 9,31E-09 & 7,52E-09 & 1,27E-08 & $1,02 \mathrm{E}-08$ \\
\hline & $(9,56 \mathrm{E}-01)$ & $(0,7526685)$ & $(1,1656777)$ & $(0,9557801)$ \\
\hline \multirow[t]{2}{*}{ GNP3 } & $-3,06 \mathrm{E}-13$ & $-2,55 \mathrm{E}-13$ & $-4,41 \mathrm{E}-13$ & $-3,86 \mathrm{E}-13$ \\
\hline & $(-1,10 \mathrm{E}+00)$ & $(-0,8877342)$ & $(-1,3433573)$ & $(-1,1986617)$ \\
\hline \multirow[t]{2}{*}{ OPEC } & & $-0,3557758$ & & $-0,7616376$ \\
\hline & & $(-1,6680916)$ & & $(-2,2581965)$ \\
\hline \multirow[t]{2}{*}{ CORR } & & & 0,350486 & 0,4928627 \\
\hline & & & $(1,4061103)$ & $(1,7578666)$ \\
\hline $\mathrm{R} 2$ & 0,035881 & 0,0429486 & 0,0660958 & 0,0935 \\
\hline $\mathrm{R} 2 \mathrm{~A}$ & 0,0075246 & 0,0050455 & 0,0291095 & 0,048175 \\
\hline$p$-value & 0.29 & 0.35 & 0.14 & 0.08 \\
\hline
\end{tabular}


Table A4: SUR Estimation

Equation: GNPPC $=C(1)+C(2)^{*} C A P P C+C(3)^{*} A D L I T+C(4)^{*} R D P E R S+C(5)^{*} C O R R$ Observations: 81

\begin{tabular}{llll}
\hline R-squared & 0.930996 & Mean dependent var & 7667.407 \\
Adjusted R-squared & 0.927364 & S.D. dependent var & 7342.937 \\
S.E. of regression & 1978.996 & Sum squared resid & $2.98 \mathrm{E}+08$ \\
Durbin-Watson stat & 2.282705 & & \\
\hline \hline
\end{tabular}

Equation: $\mathrm{SO} 2=\mathrm{C}(11)+\mathrm{C}(12)^{*} \mathrm{GNPPC}+\mathrm{C}(13)^{*} \mathrm{GNPPC}{ }^{\wedge} 2+\mathrm{C}(14)^{*} \mathrm{GNPPC}{ }^{\wedge} 3+\mathrm{C}(15)^{*} \mathrm{CORR}$ Observations: 106

\begin{tabular}{lllr}
\hline R-squared & 0.276548 & Mean dependent var & -0.001792 \\
Adjusted R-squared & 0.247897 & S.D. dependent var & 0.980256 \\
S.E. of regression & 0.850116 & Sum squared resid & 72.99249 \\
Durbin-Watson stat & 1.953807 & & \\
\hline \hline
\end{tabular}

Equation: $\mathrm{NO} 2=\mathrm{C}(21)+\mathrm{C}(22)^{\star} \mathrm{GNPPC}+\mathrm{C}(23)^{*} \mathrm{GNPPC}{ }^{\wedge} 2+\mathrm{C}(24)^{*} \mathrm{GNPPC} \mathrm{C}^{\wedge}+\mathrm{C}(25)^{*} \mathrm{CORR}$ Observations: 106

\begin{tabular}{llll}
\hline R-squared & 0.044963 & Mean dependent var & 0.024151 \\
Adjusted R-squared & 0.007139 & S.D. dependent var & 1.025079 \\
S.E. of regression & 1.021413 & Sum squared resid & 105.3717 \\
Durbin-Watson stat & 1.921381 & & \\
\hline \hline
\end{tabular}

Equation: $\mathrm{TSP}=\mathrm{C}(31)+\mathrm{C}(32)^{*} \mathrm{GNPPC}+\mathrm{C}(33)^{*} \mathrm{GNPPC}{ }^{\wedge} 2+\mathrm{C}(34)^{*} \mathrm{GNPPC}{ }^{\wedge} 3+\mathrm{C}(35)^{*} \mathrm{CORR}$ Observations: 106

\begin{tabular}{lllr}
\hline R-squared & 0.635569 & Mean dependent var & -0.037264 \\
Adjusted R-squared & 0.621136 & S.D. dependent var & 1.042154 \\
S.E. of regression & 0.641465 & Sum squared resid & 41.55927 \\
Durbin-Watson stat & 1.665968 & & \\
\hline
\end{tabular}

Equation: GMS_DO=C(41)+C(42)*GNPPC+C(43)*GNPPC^2+C(44) *GNPPC^3+

Observations: 106

$$
\mathrm{C}(45)^{*} \mathrm{CORR}
$$

\begin{tabular}{lllr}
\hline R-squared & 0.561810 & Mean dependent var & -0.008396 \\
Adjusted R-squared & 0.544456 & S.D. dependent var & 1.041626 \\
S.E. of regression & 0.703035 & Sum squared resid & 49.92014 \\
Durbin-Watson stat & 2.056768 & & \\
\hline
\end{tabular}

Equation: GMS_PH $=\mathrm{C}(51)+\mathrm{C}(52)^{*} \mathrm{GNPPC}+\mathrm{C}(53)^{*} \mathrm{GNPPC}{ }^{\wedge} 2+\mathrm{C}(54){ }^{*} \mathrm{GNPPC}{ }^{\wedge} 3+$

Observations: 106

$$
\mathrm{C}(55)^{\star} \mathrm{CORR}
$$

\begin{tabular}{lllr}
\hline R-squared & 0.048060 & Mean dependent var & -0.030472 \\
Adjusted R-squared & 0.010359 & S.D. dependent var & 0.968719 \\
S.E. of regression & 0.963688 & Sum squared resid & 93.79816 \\
Durbin-Watson stat & 2.385182 & & \\
\hline \hline
\end{tabular}

\section{Equation: GMS SS $=\mathrm{C}(61)+\mathrm{C}(62)^{\star} \mathrm{GNPPC}+\mathrm{C}(63)^{\star} \mathrm{GNPPC}{ }^{\wedge} 2+\mathrm{C}(64){ }^{*} \mathrm{GNPPC} \mathrm{C}^{\wedge} 3+$

$$
\mathrm{C}(65)^{*} \mathrm{CORR}
$$

\begin{tabular}{|c|c|c|c|}
\hline R-squared & 0.722068 & Mean dependent var & -0.053113 \\
\hline Adjusted R-squared & 0.711061 & S.D. dependent var & 1.050440 \\
\hline S.E. of regression & 0.564644 & Sum squared resid & 32.20107 \\
\hline Durbin-Watson stat & 1.837364 & & \\
\hline
\end{tabular}

Observations: 106 
Coefficient

\begin{tabular}{|c|c|c|c|c|}
\hline & & & & \\
\hline$C(1)$ & 2471.149 & 1001.451 & 2.467568 & 0.0138 \\
\hline $\mathrm{C}(2)$ & 0.134556 & 0.017110 & 7.864262 & 0.0000 \\
\hline $\mathrm{C}(3)$ & 18.03107 & 12.70216 & 1.419527 & 0.1562 \\
\hline $\mathrm{C}(4)$ & 1667.624 & 443.3781 & 3.761179 & 0.0002 \\
\hline $\mathrm{C}(5)$ & -1082.246 & 417.1904 & -2.594130 & 0.0097 \\
\hline$C(11)$ & -0.092878 & 0.257523 & -0.360657 & 0.7185 \\
\hline$C(12)$ & 0.000128 & 9.49E-05 & 1.350554 & 0.1773 \\
\hline$C(13)$ & -1.49E-08 & 9.50E-09 & -1.563519 & 0.1184 \\
\hline$C(14)$ & $3.83 E-13$ & 2.67E-13 & 1.432234 & 0.1525 \\
\hline$C(15)$ & 0.342588 & 0.169625 & 2.019685 & 0.0438 \\
\hline$C(21)$ & -0.245142 & 0.308783 & -0.793896 & 0.4275 \\
\hline$C(22)$ & 5.97E-05 & 0.000114 & 0.525090 & 0.5997 \\
\hline$C(23)$ & -1.86E-09 & 1.14E-08 & -0.163510 & 0.8702 \\
\hline$C(24)$ & $3.10 \mathrm{E}-14$ & $3.20 \mathrm{E}-13$ & 0.096760 & 0.9229 \\
\hline$C(25)$ & 0.357626 & 0.203433 & 1.757960 & 0.0792 \\
\hline$C(31)$ & 1.135569 & 0.193403 & 5.871513 & 0.0000 \\
\hline$C(32)$ & -0.000343 & $7.12 \mathrm{E}-05$ & -4.817132 & 0.0000 \\
\hline C(33) & 2.07E-08 & 7.12E-09 & 2.905010 & 0.0038 \\
\hline$C(34)$ & $-4.30 \mathrm{E}-13$ & $2.00 \mathrm{E}-13$ & -2.147568 & 0.0321 \\
\hline$C(35)$ & 0.209384 & 0.127454 & 1.642818 & 0.1009 \\
\hline $\mathrm{C}(41)$ & 0.716336 & 0.211282 & 3.390418 & 0.0007 \\
\hline $\mathrm{C}(42)$ & -0.000176 & 7.77E-05 & -2.261131 & 0.0241 \\
\hline$C(43)$ & 7.65E-09 & 7.77E-09 & 0.985202 & 0.3249 \\
\hline $\mathrm{C}(44)$ & $-1.14 \mathrm{E}-13$ & $2.18 \mathrm{E}-13$ & -0.523606 & 0.6007 \\
\hline$C(45)$ & 0.363671 & 0.139285 & 2.610974 & 0.0092 \\
\hline$C(51)$ & -0.227503 & 0.289884 & -0.784808 & 0.4328 \\
\hline$C(52)$ & -3.60E-05 & 0.000107 & -0.337657 & 0.7357 \\
\hline $\mathrm{C}(53)$ & $1.31 \mathrm{E}-08$ & 1.07E-08 & 1.231480 & 0.2186 \\
\hline$C(54)$ & $-4.65 E-13$ & $3.00 \mathrm{E}-13$ & -1.551231 & 0.1213 \\
\hline$C(55)$ & 0.308019 & 0.191084 & 1.611962 & 0.1074 \\
\hline $\mathrm{C}(61)$ & 0.874647 & 0.170089 & 5.142284 & 0.0000 \\
\hline $\mathrm{C}(62)$ & -0.000245 & 6.26E-05 & -3.911185 & 0.0001 \\
\hline$C(63)$ & $1.11 \mathrm{E}-08$ & 6.26E-09 & 1.780054 & 0.0755 \\
\hline$C(64)$ & $-1.45 E-13$ & $1.76 \mathrm{E}-13$ & -0.820841 & 0.4120 \\
\hline$C(65)$ & 0.404214 & 0.112101 & 3.605796 & 0.0003 \\
\hline
\end{tabular}

